OPEN ACCESS

Edited by:

Martin Guitreau,

Université Clermont Auvergne, France

Reviewed by:

Allen Phillip Nutman,

University of Wollongong, Australia

Mingguo Zhai,

Chinese Academy of Sciences (CAS),

China

${ }^{*}$ Correspondence:

Adam Andreas Garde aag@geus.dk

Specialty section: This article was submitted to Petrology, a section of the journal

Frontiers in Earth Science

Received: 06 March 2020

Accepted: 15 October 2020

Published: 18 December 2020

Citation:

Garde AA, Windley BF, Kokfelt TF and Keulen N (2020) Archaean Plate Tectonics in the North Atlantic Craton of West Greenland Revealed by WellExposed Horizontal Crustal Tectonics, Island Arcs and Tonalite-Trondhjemite-

Granodiorite Complexes.

Front. Earth Sci. 8:540997.

doi: 10.3389/feart.2020.540997

\section{Archaean Plate Tectonics in the North Atlantic Craton of West Greenland Revealed by Well-Exposed Horizontal Crustal Tectonics, Island Arcs and Tonalite-Trondhjemite-Granodiorite Complexes}

\author{
Adam Andreas Garde ${ }^{1 *}$, Brian Frederick Windley ${ }^{2}$, Thomas Find Kokfelt ${ }^{1}$ and Nynke Keulen ${ }^{1}$ \\ ${ }^{1}$ Geological Survey of Denmark and Greenland, Copenhagen, Denmark, ${ }^{2}$ Department of Geology, University of Leicester, \\ Leicester, United Kingdom
}

The $700 \mathrm{~km}$-long North Atlantic Craton (NAC) in West Greenland is arguably the best exposed and most continuous section of Eo-to Neoarchaean crust on Earth. This allows a close and essential correlation between geochemical and isotopic data and primary, welldefined and well-studied geological relationships. The NAC is therefore an excellent and unsurpassed stage for the ongoing controversial discussion about uniformitarian versus non-uniformitarian crustal evolution in the Archaean. The latest research on the geochemistry, structural style, and $\mathrm{Hf}$ isotope geochemistry of tonalite-trondhjemitegranodiorite (TTG) complexes and their intercalated mafic to intermediate volcanic belts strongly supports previous conclusions that the NAC formed by modern-style plate tectonic processes with slab melting of wet basaltic oceanic crust in island arcs and active continental margins. New studies of the lateral tectonic convergence and collision between juvenile belts in the NAC corroborate this interpretation. Nevertheless, it has repeatedly been hypothesised that the Earth's crust did not develop by modern-style, subhorizontal plate tectonics before $3.0 \mathrm{Ga}$, but by vertical processes such as crustal sinking and sagduction, and granitic diapirism with associated dome-and-keel structures. Many of these models are based on supposed inverted crustal density relations, with upper Archaean crust dominated by heavy mafic ridge-lavas and island arcs, and lower Archaean crust mostly consisting of felsic, supposedly buoyant TTGs. Some of them stem from older investigations of upper-crustal Archaean greenstone belts particularly in the Dharwar craton, the Slave and Superior provinces and the Barberton belt. These interpreted interactions between these upper and lower crustal rocks are based on the apparent down-dragged greenstone belts that wrap around diapiric granites. However, in the lower crustal section of the NAC, there is no evidence of any low-density granitic diapirs or heavy, downsagged or sagducted greenstone belts. Instead, the NAC contains wellexposed belts of upper crustal, arc-dominant greenstone belts imbricated and intercalated by well-defined thrusts with the protoliths of the now high-grade TTG gneisses, followed by crustal shortening mainly by folding. This shows us that the upper and lower Archaean 
crustal components did not interact by vertical diapirism, but by subhorizontal interthrusting and folding in an ambient, mainly convergent plate tectonic regime.

Keywords: plate tectonics, North Atlantic Craton, andesitic arc volcanism, epithermal Au deposits, epsilon Hf, Maniitsoq impact structure, Archaean

\section{INTRODUCTION}

The Archaean craton in West Greenland is a key part of the North Atlantic Craton (NAC) (Bridgwater et al., 1973a, Bridgwater et al., 1973b; Nutman, 1997). The excellent three-dimensional exposures along this $\mathrm{N}-\mathrm{S}, 700 \mathrm{~km}$-long craton makes this one of the most informative transects of Archaean crust on Earth, especially because it contains many intercalated sections of both upper- and lowercrustal rocks and their connected structures that are rarely available in granite-greenstone terrains. It was first realised by Windley and Bridgwater (1971) that high-grade Precambrian gneiss belts primarily consist of strongly deformed, mostly TTG (tonalitetrondhjemite-granodiorite) orthogneisses, and rarely include rocks of sedimentary origin as normally seen in granite-greenstone belts. The distinction between Eo- and Mesoarchaean orthogneisses in the Nuuk region (McGregor, 1973) led to the recognition of large-scale, subhorizontal, tectonic intercalation of older and younger crustal segments (Bridgwater et al., 1974), and later to the concept of Archaean tectono-stratigraphy (e.g., Friend et al., 1988; Nutman et al., 1989; Friend and Nutman, 2019) where individual terranes with specific lithologies, ages and tectonic histories were recognised within the central NAC, and later found to be applicable to the Canadian Superior Province (e.g., Polat et al., 2009).

Subsequently, the Greenlandic NAC continued to yield abundant field, geochemical and geochronological evidence of Archaean crustal accretion/evolution by plate tectonic processes, including identification of andesitic calc-alkaline metavolcanic rocks in supra-subduction zone island arcs intercalated with TTG gneisses. Following the terrane accretion models of Friend et al. (1987), Friend et al. (1988), McGregor et al. (1991) made the first specific Archaean plate tectonic model for the Godthåbsfjord region. These and other papers with relevant data were summarised by Windley and Garde (2009) who reported strong evidence for the operation of plate tectonic processes in the Meso-to Neoarchaean of West Greenland. In the following we particularly examine more recent research, except for the NAC in East Greenland which still lacks many detailed studies. We finally address if non-uniformitarian models of Archaean crustal evolution might be viable alternatives to the accumulated field and geochemical data from the large, wellexposed, representative rocks in West Greenland.

\section{MAIN COMPONENTS OF THE NORTH ATLANTIC CRATON IN WEST GREENLAND}

\section{Components of the Eoarchaean Itsaq Gneiss Complex}

The largely Mesoarchaean craton of West Greenland contains the extensively studied, NE-trending Eoarchaean Itsaq Gneiss Complex. McGregor (1973) made his outstanding breakthrough in Archaean history at the southern end of this belt, around the town of Nuuk (formerly Godthåb). The 3.8-3.6 Ga Eoarchaean belt, which is about $180 \mathrm{~km}$ long (Nutman et al., 1996; Nutman et al., 2013), consists primarily of TTG orthogneisses, within which there are many relict layers, lenses and large bodies of a variety of rocks, particularly in the Isua supracrustal belt in the north and on Akilia island and nearby areas in the south (e.g., Nutman et al., 2020; van de Löcht et al., 2020). Eoarchaean orthogneisses also occur in the Aasivik terrane north of the Itsaq Gneiss Complex (Figure 1; Rosing et al., 2001).

\section{Isua Supracrustal Belt}

The $10 \times 25 \mathrm{~km}$ Isua supracrustal belt is the oldest $(3.8-3.7 \mathrm{Ga})$ supracrustal belt in the world (the older Acasta belt in Canada is gneissic and not strictly supracrustal), which mainly consists lithologically of (meta-) basaltic volcanic rocks including massive flows, pillow lavas, pillow breccias, volcaniclastic sediments, basaltic dykes and sills, gabbros and ultramafic rocks, minor felsic volcanic rocks, together with bedded cherts, magnetite-facies BIF, monomict and polymict conglomerates, and turbidites (Maruyama et al., 1991; Nutman et al., 1997a; Nutman et al., 1997b; Appel et al., 1998; Komiya et al., 1999; Nutman and Friend, 2009; Arai et al., 2015). These supracrustal rocks were intruded by a variety of tonalites and diorites, which are now mostly orthogneisses (Nutman et al., 2009).

The existence of surface water at 3.8-3.7 Ga is indicated in Isua by the presence of pillow lavas (Maruyama et al., 1991; Appel et al., 1998; Maruyama and Komiya, 2011) and of bedded sediments such as pelagic cherts and banded iron formation (BIF) (Moorbath et al., 1973; Nutman et al., 1997b). According to Maruyama and Komiya (2011) the total thickness of the largest unit of pillow basalts in Isua is up to $1.0 \mathrm{~km}$, suggesting that the ambient ocean depth was at least $1.0 \mathrm{~km}$; from the presence of vesicular basalts de Wit and Furnes (2013) suggested a depth of up to $2-4 \mathrm{~km}$. By using the source mantle potential temperature of $1,450^{\circ} \mathrm{C}$ and the ocean surface temperature of $100^{\circ} \mathrm{C}$ in the Early Archaean by Komiya (2004), Komiya (2007) and Komiya et al. (1999), which compare with the corresponding temperatures of the modern Earth of 1,330 and $0^{\circ} \mathrm{C}$, respectively, Maruyama and Komiya (2011) calculated the oceanic geotherm of the Early Archaean lithosphere and concluded that the lithosphere was sufficiently rigid to operate modern-style plate tectonics in Isua times. Frei and Polat (2007) used isotopic relations in the Isua BIF to demonstrate that two rare-earth element (REE) sources were derived from sea-floor vented hydrothermal fluids and from ambient surface seawater that were responsible for the iron- and silica-rich layers, implying that the silica was derived from a now-unexposed mafic 


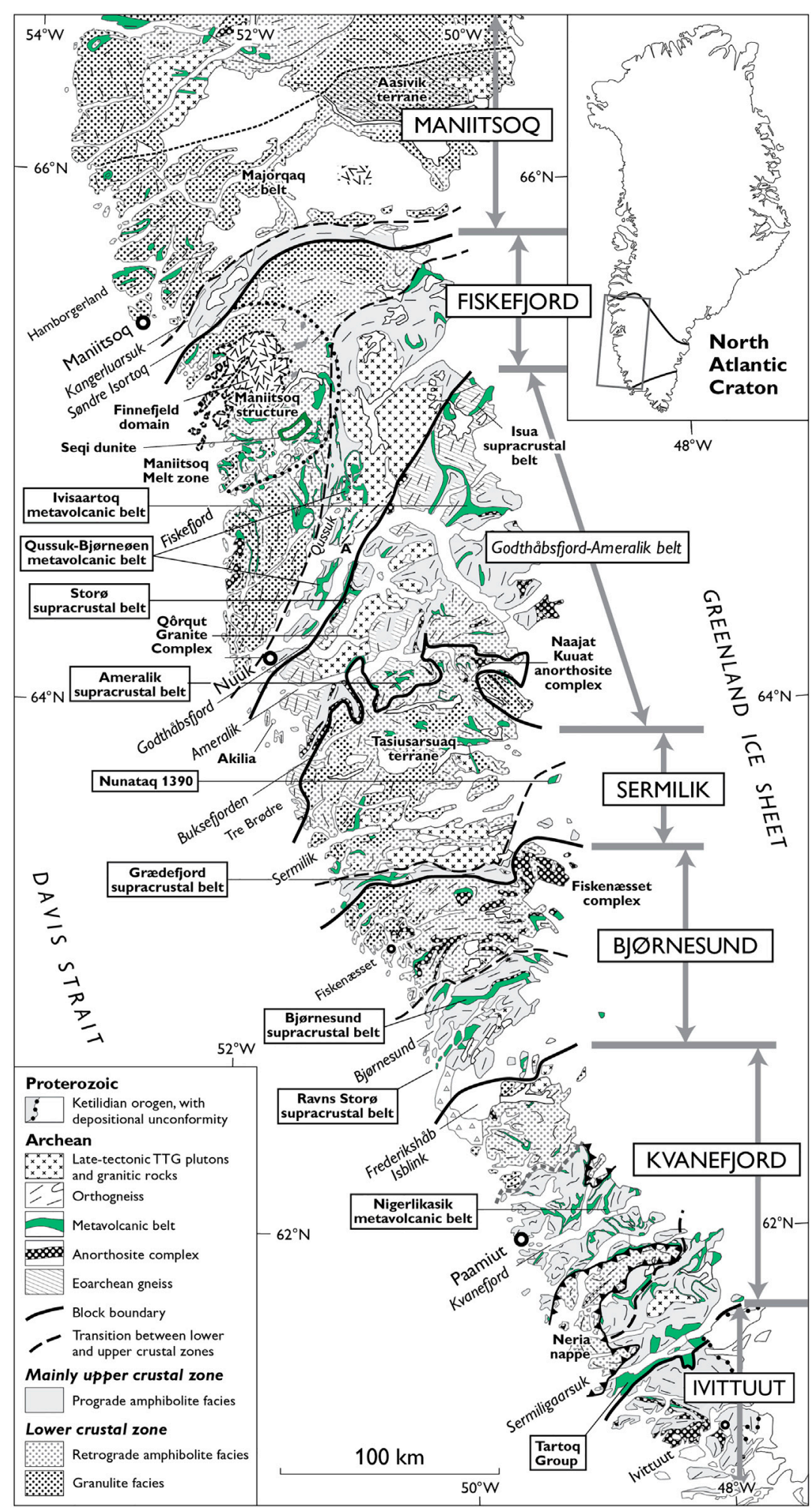

FIGURE 1 | Meso-to Neoarchaean crustal blocks in the West Greenland NAC (Windley and Garde, 2009), showing Upper and Lower Zone geological units and place names as outlined in the text. All Upper Zones contain bimodal metavolcanic belts with well-preserved andesitic arc components. A. Ataneq fault (adjacent to Qussuk). The Akia and Tasiusarsuaq terranes (Nutman et al., 1989) largely overlap the Fiskefjord and Sermilik-Bjørnesund blocks, respectively. Modified from Windley and Garde (2009). Triangular symbols are Quaternary cover. 
landmass. Friend et al. (2008) demonstrated that the Isua BIF has modern seawater-like trace element signatures consistent with chemical sedimentation from seawater with little clastic input at $c$. 3.7 Ga. In a more detailed geochemical study of the Isua BIF Aoki et al. (2018) showed that with stratigraphic height the ratio of hydrothermal fluid to seawater component decreased throughout the period of deposition with increasing distance from a ridge to a trench in common with the changes in modern sediments on a spreading oceanic plate, confirming the role of ocean plate stratigraphy (OPS, see below) in the plate-tectonic history of Isua.

\section{Akilia Island}

Akilia island at the southern end of the Itsaq Gneiss Complex consists of amphibolites, ultramafic rocks, a controversial $\mathrm{Fe}-\mathrm{Mg}$ amphibole-quartz-pyroxene rock, a minor anthophyllite-garnet rock of possible sedimentary parentage, and TTG orthogneiss (McGregor and Mason, 1977; Nutman et al., 1996; Myers and Crowley, 2000; Nutman et al., 2002; Manning et al., 2006). The quartz-pyroxene rock, which looks like BIF in the field (Friend et al., 2008) consists of alternating layers of quartz vs. hedenbergitic clinopyroxene, Fe-Mg amphibole \pm garnet, apatite and magnetite. The "Akilia controversy" (Whitehouse et al., 2009) arose when Mojzsis et al. (1996) and McKeegan et al. (2007) reported that the quartz-pyroxene rock contained biogenic graphite, apatite, and graphite inclusions in apatite, which has major implications for possible life on Earth at $>3,800$ Ma. Dauphas et al. (2004) supported the biogenic idea, but Fedo and Whitehouse (2002), Lepland et al. (2005), Nutman and Friend (2006) and Whitehouse et al. (2009) found no evidence for such an origin.

\section{Lithological, Structural, Geochronological and Geochemical Models for the Isua Supracrustal Belt}

The tectonic significance of the Isua belt revolves around three main conceptual models of how to interpret the complex interrelationships of an orogenic belt. The lithology/structure-based, the chronology/structure-based, and the geochemicallyconstrained model. Each model takes account of field-based structures, albeit in different ways, and they all interpret the Isua belt in terms of modern-style plate tectonics (for a different view see Webb et al., 2020).

\section{The Lithology/Structure-Based Model}

The first major model to explain the Isua geology came from the Maruyama-Komiya team, who with their experience of the Mesozoic OPS in Japan discovered essentially identical OPS in NE Isua (Maruyama et al., 1991; Komiya et al., 1999) followed by Maruyama and Komiya (2011) and Arai et al. (2015). Ocean plate stratigraphy (OPS) is a bulk term that describes the travel history of an opening-closing oceanic plate from basalts, gabbros and ultramafic rocks that form at a mid-oceanic ridge to pelagic cherts and/or carbonates that accumulate during the movement of the ocean toward its trench. When the outer trench slope is reached hemipelagic mudstones are deposited on the cherts, and succeeded by voluminous clastic turbidites, greywackes and conglomerates that may be derived by erosion of the accretionary wedge, the adjacent volcanic arc, or an eroded old craton behind the arc (Kusky et al., 2013). The key point relevant for this discussion is that the sequentially developed package of basalt-chert-turbidite can be recognised in many accretionary orogens from the Eoarchaean to the Cenozoic worldwide. As all the maps of any origin show, this tripartite package is clearly present in NE Isua (but see GeochemicallyConstrained Models regarding basalt compositions). It represents the core of the argument that Isua developed as an accretionary orogen little different from those of the Phanerozoic.

\section{The Chronology/Lithology-Based Model}

The second major model to explain Isua geology comes from the Nutman-Friend team (Nutman et al., 1996; Nutman et al., 1997a; Nutman et al., 1997b; Nutman et al., 2004; Nutman and Friend, 2009; Nutman et al., 2010; Nutman et al., 2013; Nutman 2015a; Nutman et al., 2015b; Friend and Nutman, 2019), who used abundant zircon ages mostly of (meta-) tonalites and diorites to work out the sequential development of two main terranes in NE Isua; a southern $c .3 .8 \mathrm{Ga}$ and a northern $c$. $3.7 \mathrm{Ga}$ terrane. The central boundary between the terranes is a mylonitised belt of chert, BIF and carbonate rocks that contain 3,940-3,750 Ma detrital zircons (Nutman and Friend, 2009). The northern, younger terrane is an imbricate package with no preserved stratigraphy, composed of arc components that young from $c$. 3,720-3,715 Ma boninites (Polat et al., 2002), tholeiites and picrites (Polat et al., 2002), to $c$. 3,710-3,700 Ma andesites, lesser dacites and sediments derived from them, to $c .3,700-3,695 \mathrm{Ma}$ BIF and minor zircon-bearing siliceous detritus from a distal source (Nutman and Friend, 2009). The older southern terrane contains a similar arc assemblage and is similar in origin to the northern terrane, but it contains minor $>3,850 \mathrm{Ma}$ crust. This (now-thin) central boundary belt probably acted as a décollement when the northern younger, c. $3.7 \mathrm{Ga}$, terrane was thrust southwards over the southern older, c. $3.8 \mathrm{Ga}$, terrane.

Although Nutman and Friend (2009) and Nutman et al. (2009) considered that Isua developed by accretionary processes at a convergent plate margin similar to those operating in the modern Earth, their tectonic development by upward younging of the accretionary belt is the opposite of the younging downward polarity recognised in the accretionary wedges of modern subduction zones, and in accretionary orogens of any age (e.g., Leggett et al., 1979; Platt 1986; Kawai et al., 2007; Isozaki et al., 2010; Kusky et al., 2013).

\section{Geochemically-Constrained Models}

Komiya et al. (1999) considered that the basalts in Isua were generated at a mid-oceanic ridge, and Komiya et al. (2004) reported that some basalts have MORB and others have OIB chemistry. However, detailed trace element geochemistry demonstrated that all the basalts in Isua have island arc chemistry (Polat et al., 2002; Nutman and Friend, 2009). This problem is related to the tectonic divisions in Isua as explained in The Lithology/Structure-Based Model and The Chronology/ Lithology-Based Model above. Komiya et al. (1999) defined eight units (mostly across the northern $3.7 \mathrm{Ga}$ zone of Nutman and Freind, 2009) of OPS, which are all separated by thrusts and 
underlain by massive and pillow basalts, representing the whole OPS history of Isua. Because the early traverses of Komiya et al. (1999) crossed some of the later isotopically-defined units and boundaries of Nutman and Friend (2009), and because Polat et al. (2002) and Nutman and Friend (2009) found that all the basalts have island arc chemistry, inevitably Nutman and Friend (2009) do not believe the OPS units and structural set-up of Komiya et al. (1999), but consider that their three zones developed separately and at different times and were juxtaposed by accretionary collisions. Kamber et al. (2001) made a critical assessment of the isotopic constraints on the evolution of Isua rocks. However, we will not comment further, as it is beyond the scope of this paper to present a comparative detailed analysis of these opposing geochemical arguments.

\section{The Mesoarchaean Sections of the Greenland Craton}

A plate-tectonic model for the central part of the West Greenland NAC was first proposed by McGregor et al. (1991). In the entire NAC of West Greenland Windley and Garde (2009) proposed a repetitive pattern of crustal tilting into six large blocks with tectonic boundaries (Ivittuut, Kvanefjord, Bjørnesund, Sermilik, Fiskefjord and Maniitsoq, Figure 1). Each block except Maniitsoq comprises a transition from granulite facies, lower zones in the north to unretrogressed amphibolite facies upper zones in the south, with intervening rocks partially retrogressed to upper amphibolite facies. The block boundaries were originally drawn to bring out this general pattern. Some have been revised in Figure 1, and further revisions may be required as new information from less intensely studied regions becomes available.

The lower, deep-crustal zones of the blocks are dominated by highly ductile, double/triple fold interference patterns that overprint earlier thrusts and recumbent isoclinal folds. They comprise TTG gneisses with subordinate, kilometre-sized belts, small rafts and enclaves of homogeneous to indistinctly layered amphibolites that rarely preserve primary structures. Like mafic counterparts in the upper zones they have MORB-like compositions that contain minor but important layers of anorthositic complexes, like Fiskenaesset (Figure 1), and layers and enclaves of amphibolites, which like their mafic counterparts in the upper zones have MORB-like compositions and flat chondrite-normalised REE patterns.

The upper zones display simpler, less ductile structures and contain better-preserved intrusive contacts and thrustintercalated volcanic and plutonic components. They contain well-defined remnants of volcanic arcs with recognisable pillow basalts, lapilli tuffs and andesitic volcaniclastic rocks. The arcs are bimodal in composition, with tholeiitic mafic and calc-alkaline andesitic components (Table 1; Testing Mesoarchaean Plate Tectonics in West Greenland: Recent Field and Laboratory Results; Szilas et al., 2018). Many of these metavolcanic belts are associated with contemporaneous, intrusive, layered anorthositic complexes believed to have crystallised from hydrous tholeiitic magmas. The Fiskenæsset complex in the Bjørnesund block (Figure 1) is the most extensive, best exposed and most well-studied Mesoarchaean layered anorthositic complex worldwide (see Fiskenosset Complex).
Most parts of the craton also contain I-type granitic rocks, which are contemporaneous with, or younger than the TTG complexes, and generally interpreted as melts of mafic crust (Rapp et al., 2010; Friend and Nutman, 2019).

\section{TESTING MESOARCHAEAN PLATE TECTONICS IN WEST GREENLAND: RECENT FIELD AND LABORATORY RESULTS}

\section{Tonalite-Trondhjemite-Granodiorite Orthogneisses}

Mesoarchaean TTG orthogneisses make up about $80 \%$ of the West Greenland NAC (Kalsbeek and Myers, 1973; Wedepohl et al., 1991; Friend and Nutman, 2019). Much earlier work on the TTG orthogneisses addressed general magmatic and tectonic aspects, demonstrating that they are invariably younger than and intrusive into the metavolcanic belts, and/or they are mutually thrust-intercalated (Myers, 1976; Kisters et al., 2012; Keulen et al., 2014; Polat et al., 2016; Szilas et al, 2018). Early thrusts and recumbent isoclinal folds were refolded by several phases of ductile folds in the lower crust and by simpler, upright compressional folds in the middle-upper crust (e.g., Berthelsen, 1960; Garde, 1997; Windley and Garde, 2009). The TTG protoliths were intruded as subhorizontal sheets synchronous with, but mainly following, the emplacement of the layered anorthositic complexes (Myers, 1976), which enabled the widespread breakup of the complexes and their host metavolcanic rocks into inclusions in the TTG gneisses, most spectacularly seen in the Ivittuut region (Berthelsen and Henriksen, 1975; Windley and Garde, 2009). We note that exactly the same process occurs in the upper crust of modern accretionary orogens, like Japan where peraluminous tonalites were intruded along thrust planes during subhorizontal tectonics and granulite facies metamorphism in the Tertiary Hidaka arc-trench system (Komatsu et al., 1989).

The major and trace element compositions of the Greenlandic TTG orthogneisses repeatedly indicate a characteristic depletion in $\mathrm{Nb}$, Ta and heavy rare-earth elements, which is consistent with slab melting in a subduction zone with local mantle wedge interaction (Steenfelt et al., 2005). Experimental studies have commonly demonstrated that the magmatic generation of such TTG rocks requires a component of slab melting from hydrated mafic crust and a melt component from previously depleted mantle (Arth and Hanson, 1972; Winther and Newton, 1991; Rapp et al., 2010; Moyen and Martin, 2012). This important observation supports Mesoarchaean plate subduction, which might indicate a high potential mantle temperature in the early Earth (Komiya, 2007; Herzberg et al., 2010), or alternatively it might mean that warmer, ridge-subducted, crust was being subducted, as in the modern Earth (Arndt, 2013).

Gardiner et al. (2019) presented major, trace element, isotope and geochronological data for a large number of orthogneisses in the northern part of the Finnefjeld block, which are similar to those in other parts of the NAC. They also compared the average 


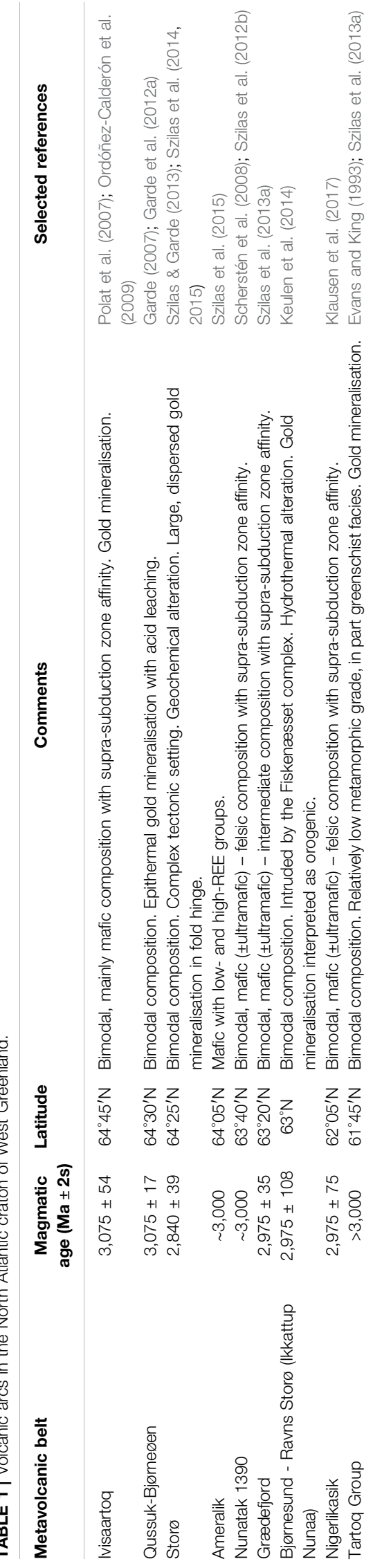

composition of the TTG gneisses surrounding the Finnefjeld domain with that of the rocks within this domain, which had previously been shown to consist of cataclastic rocks comprising both TTG and metavolcanic rocks (Garde et al., 2014; see The Maniitsoq Structure). The Finnefjeld rocks have $\sim 3,000 \mathrm{Ma}$ zircon $\mathrm{U}-\mathrm{Pb}$ ages which are identical to those in the surrounding orthogneisses, but lower $\mathrm{SiO}_{2}$ and higher $\mathrm{TiO}_{2}$, $\mathrm{FeOt}, \mathrm{MgO}$ and $\mathrm{CaO}$, as well as significantly higher HREE.

Abundant additional age data from the TTG gneisses in the different blocks have been published in the last decades, too numerous to be reviewed here; the most important age groups in the Nuuk region can be gleaned from Examination of Continental Growth Using Trace Element and Hafnium Isotope Compositions, see also Friend and Nutman (2019). Significant in the present context are the relative ages of adjacent metavolcanic belts (older) and TTG orthogneisses (younger).

\section{Examination of Continental Growth Using Trace Element and Hafnium Isotope Compositions}

The development of more precise trace element, geochemical and isotope analytical tools and decreasing funding for systematic field work changed the nature of recent studies in the Earth sciences and led to new tests of older crustal accretion models.

$\mathrm{A} \mathrm{Nb} / \mathrm{Yb}$ vs. Th/Yb diagram (Figure 2) of the metabasaltic rocks from each of the Meso-to Neoarchaean supracrustal belts in the West Greenland NAC (Table 1) illustrates potential relationships between their basaltic source magmas and Archaean continental crust as explained in the figure caption. See also the generalised Figure 10 in Szilas (2018). The element ratios straddle the present-day MORB-OIB array, forming diagonal trends that extend toward an approximate Archaean continental crustal composition. We interpret this to reflect interaction between uncontaminated magmas along the oceanic basalt array and crustal compositions above it. The ranges of the measured ratios indicate wide variations in the crustal input. There is also a remarkable age and geographical coupling: the Grædefjord, Ikkattup Nunaa and Nigerlikasik belts in the south generally have younger magmatic ages (see Andesitic Metavolcanic Arcs and Gold Mineralisation) and higher $\mathrm{Th} / \mathrm{Nb}$ ratios than the northern belts, suggesting more pronounced crustal material in the former belts; the southern belts may comprise inboard, continental arc systems, with outboard, more oceanic arc systems in the northern belts.

In the last decade several studies of zircon $\mathrm{Hf}$ isotope data from the West Greenland NAC have been published. Hiess et al. (2009) showed that metaplutonic and metavolcanic rocks from the 3.85-3.69 Ga Itsaq Gneiss Complex (see Main Components of the North Atlantic Craton in West Greenland), all have chondritic $\varepsilon H f$ values, i.e., close to zero within analytical uncertainty, and argued that processes of crustal growth must have operated incrementally during the Hadean and Eoarchaean. Næraa et al. (2012) presented complementary Hf isotope data from the Nuuk region including zircon in TTG gneisses and detrital zircons in rocks of Eo-to Neoarchaean age, thus providing a more complete view of the TTG melt source evolution (Figure 3). Their 


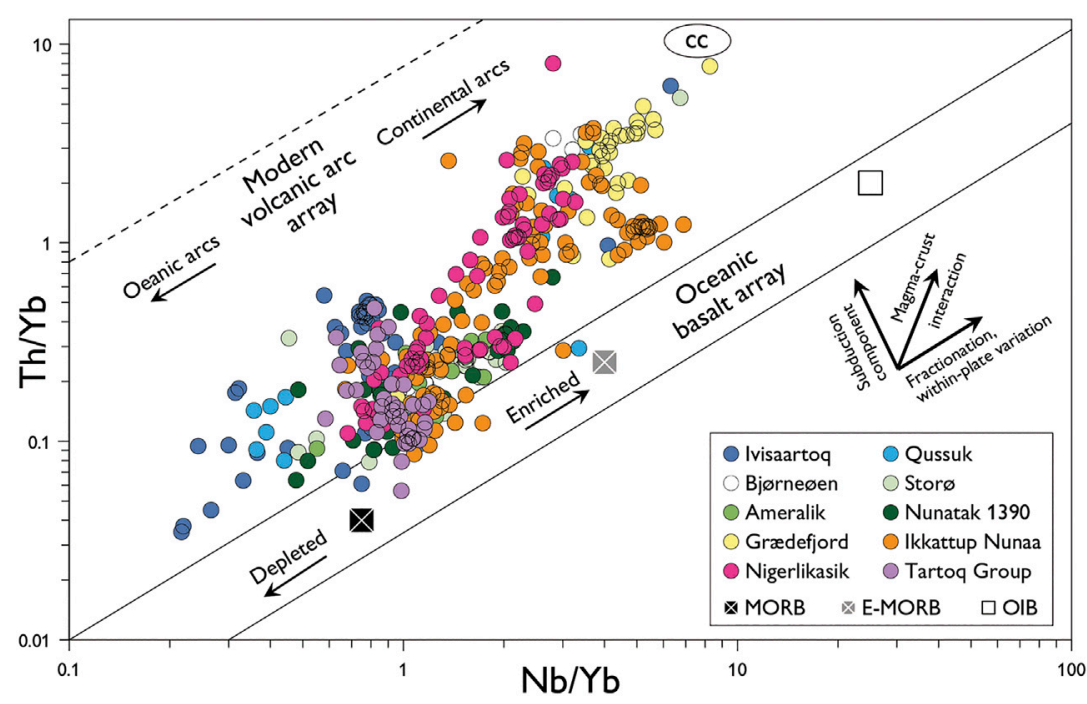

FIGURE 2 | Pearce diagram of Nb/Yb vs. Th/Yb compositions in metabasaltic rocks from the Meso-to Neoarchaean supracrustal belts listed in Table 1, suggesting input of continental crust (CC) into the precursor magmas in agreement with field evidence of arc magmatism (see main text). In this diagram (originally developed to investigate crustal influence on basaltic rocks), uncontaminated modern MORB and OIB samples define an oceanic basalt array that reflects variable amounts of recycled oceanic crust in their mantle sources. Crustal rocks, as well as basaltic magmas affected by partial crustal melting or crustal contamination, have higher Th/Nb ratios and plot above this array. Their relative Th/Nb enrichment reflects a stronger $\mathrm{Nb}$ than Th retention in the subducting slab. All modern arc-related basalts plot above the oceanic basalt array, forming a high-Th/Nb volcanic arc array which univocally signifies a crustal influence on these subduction-related basalts, either through recycling detrital sediment into the mantle source region via subduction or subsequent assimilation in the crust. The diagram can also portray relative depletion and enrichment of basalts, as more depleted basalts have lower $\mathrm{Nb} / \mathrm{Yb}$ and $\mathrm{Th} / \mathrm{Yb}$ ratios. Notably, a crustal input through a subduction component will affect the $\mathrm{Nb} / \mathrm{Yb}$ and Th/Yb ratios of depleted magmas more strongly than in enriched magmas, due to their much lower incompatible element content. This means that for any given amount of crustal addition to a mantle source, a depleted magma will be shifted to a point significantly higher above the oceanic basalt array than an enriched magma.

Hf isotope dataset replicated the chondritic Eoarchaean signature of Hiess et al. (2009), but also revealed a broad trend of declining $\varepsilon_{\mathrm{Hf}}$ values from 0 at $\sim 3.85 \mathrm{Ga}$ to -8 at $3.25 \mathrm{Ga}$, with a distinct lack of depleted $\mathrm{Hf}$ isotope signatures (i.e., high $\varepsilon_{\mathrm{Hf}}$ values) between $c$. 3.6-3.25 Ga. Næraa et al. (2012) noted there are no known exposures of felsic crust and only very few detrital zircons in this region within the latter time interval, and thus coupled the lack of depleted Hf isotope signatures to a paucity in juvenile mantle input to the crust during this time. Although some of the detrital grains plotting along the declining $\varepsilon_{\mathrm{Hf}}$ trend might reflect post-crystallisation disturbance (see, e.g., Guitreau et al., 2019), the enriched anchor point, which is represented by Fe-rich gneisses from the inner part of Ameralik Fjord, is unquestionably robust. The isotopically enriched Fe-rich gneisses clearly demonstrate that a $\sim 3.85 \mathrm{Ga}$ old mafic protolith was available at $3.25 \mathrm{Ga}$ as a source for TTG magmatism (Næraa et al., 2012) and much later for the $2.55 \mathrm{Ga}$ Qôrqut granite complex.

In contrast, the zircons in TTG gneisses that formed after $3,250 \mathrm{Ma}$ have highly variable $\varepsilon_{\mathrm{Hf}}$ compositions ranging intermittently from supra-to highly sub-chondritic values, which indicates renewed influx of juvenile material derived from a depleted mantle source along with contributions from evolved Eoarchaean crust with negative $\varepsilon_{\mathrm{Hf}}$ compositions. Næraa et al. (2012) pointed out a clear coupling between the existence of volcanic supracrustal belts and the formation of depleted TTGs and noted that this pattern of periodic juvenile arc accretion and TTG flare-ups is more consistent with Mesoarchaean continental crust evolving in accretionary orogens than by amalgamation of truly exotic terranes. Overall, Næraa et al. (2012) interpreted their data to suggest that continental crust grew from $3.2 \mathrm{Ga}$ ago in a geodynamic regime analogous to that of modern plate tectonics.

In another study of zircon $\varepsilon_{\mathrm{Hf}}$ compositions in TTG gneisses from the northern Fiskefjord block with a narrower age range, Gardiner et al. (2019) made similar arguments. As shown in Figure 3, their zircon $\varepsilon_{\mathrm{Hf}}$ data between 3.25 and $2.95 \mathrm{Ga}$ overlap with those of Næraa et al. (2012), whereas younger, remelted granitic rocks have more negative $\varepsilon_{\mathrm{Hf}}$ compositions consistent with reworking of old crust to form these rocks.

Several other studies in West Greenland have constrained the sources of metavolcanic belts using bulk-rock Lu-Hf and Sm-Nd isotope data combined with best estimates of their zircon $\mathrm{U}-\mathrm{Pb}$ magmatic ages (e.g., Hoffmann et al., 2011; Szilas et al., 2015; Szilas et al., 2016a; Szilas et al., 2017). In general, the initial $\varepsilon_{\mathrm{Hf}}$ compositions of the mafic and andesitic rocks corroborate the interpretation of Næraa et al. (2012) that the Mesoarchaean crust in West Greenland was primarily formed by melt extraction from a depleted mantle source rather than by recycling of older crust, and that the underlying magmatic processes were both variable and complex (see also Friend et al., 2009). Some whole-rock isotopic data even suggest extraction from sources with $\varepsilon_{\mathrm{Hf}}$ compositions above that of depleted mantle (Figure 3). Studying mafic and andesitic rocks of the Qussuk-Bjørneøen metavolcanic belt in the south-eastern Fiskefjord block, Szilas et al. (2017) combined whole-rock Lu-Hf isotope data with trace element compositions and showed that the andesitic rocks have 

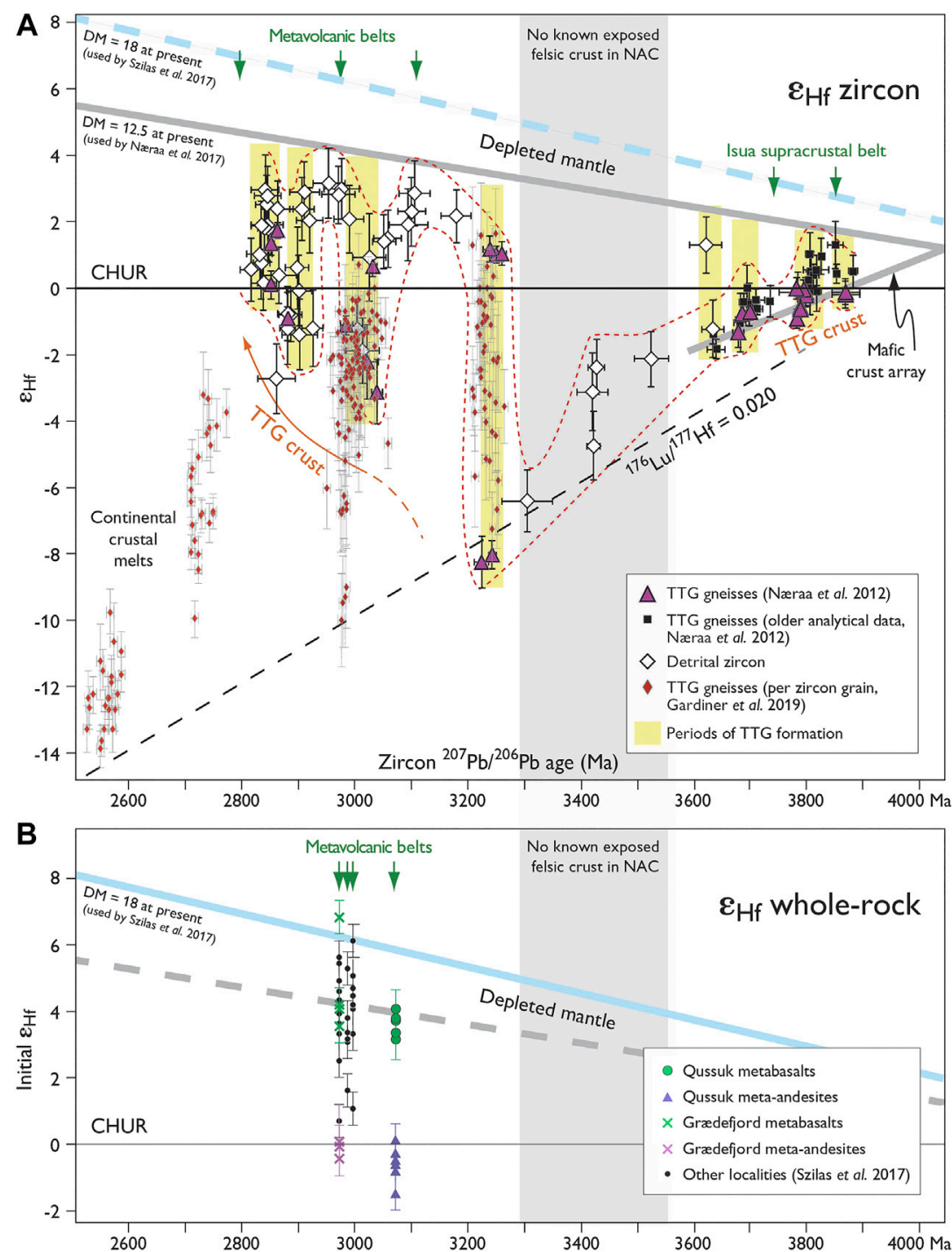

FIGURE 3 | Plots of (A) zircon and (B) whole-rock $\varepsilon_{\mathrm{Hf}}$ values for Archaean rocks in the North Atlantic craton of West Greenland, compiled from Næraa et al. (2012), Szilas et al. (2017) and Gardiner et al. (2019). Best estimates of the magmatic ages of the respective supracrustal belts are shown with green arrows. The combined measurement of $\mathrm{Lu}-\mathrm{Hf}$ and $\mathrm{U}-\mathrm{Pb}$ isotope compositions in zircon have proven a valuable tool for extracting information about the timing of mineral growth and the radiogenic enrichment of the source from which the zircon grew. While the U-Pb system dates the timing of crystallisation or recrystallisation of the zircon $\mathrm{Hf}$ isotope composition expresses the degree to which the host melt was derived from a radiogenic reservoir (i.e., positive $\varepsilon_{\mathrm{Hf}}$ values; e.g., depleted mantle) or an unradiogenic reservoir (i.e., negative $\varepsilon_{\mathrm{Hf}}$ Values; e.g., ancient continental crust), or some mixture of these sources (Spencer et al., 2020). (A) The $\varepsilon_{\mathrm{Hf}}$ zircon data from TTG rocks suggest episodic growth of the continental crust (TTG formation) from a depleted mantle source at specific times, marked by the yellow bars. Between 3.65 and 3.25 Ga there are no known exposures of felsic crust in the NAC and very few detrital zircons. The shift toward higher (depleted) $\varepsilon_{\mathrm{Hf}}$ values after $\sim 3.25$ Ga indicates a change toward more pristine sources for TTG magmatism, which in turn suggests a change in the crustal evolution toward a more modern style of plate tectonics. (B) The whole-rock $\varepsilon_{\mathrm{Hf}}$ values in the metavolcanic belts show a surprisingly large range, indicating different, variously depleted mantle sources and, in some rocks, admixture of crustal components with negative $\varepsilon_{\mathrm{Hf}}$ values. Note that the highest $\varepsilon_{\mathrm{Hf}}$ values require a more extreme depleted mantle evolution line than that shown in diagram (A).

enriched incompatible trace element compositions but nearchondritic initial $\varepsilon_{\mathrm{Hf}}$ compositions, whereas the mafic rocks have more depleted $\varepsilon_{\mathrm{Hf}}$ compositions about +4 and lessenriched trace element compositions. They concluded that the andesitic metavolcanic rocks could only have formed by mixing of contemporaneous mafic and felsic magmas. This is consistent with the most widely accepted general models for the generation of modern andesitic arcs (e.g., Isozaki et al., 2010; Stern, 2010).
In summary, the large variations in whole-rock and zircon $\varepsilon_{\mathrm{Hf}}$ compositions of juvenile Mesoarchaean volcanic belts and TTG gneisses clearly show that the generation of new Mesoarchaean crust was not simply controlled by direct extraction of melts from an increasingly depleted mantle source, but also involved incorporation of older crustal material, pointing to contamination and/or mixing of melts from different sources. The observation that the periods with the most abundant TTG 
magmatism are associated with negative excursions in $\varepsilon_{\mathrm{Hf}}$ suggests increasing degrees of contemporaneous crustal reworking (Næraa et al., 2012).

\section{Andesitic Metavolcanic Arcs and Gold Mineralisation}

As noted in the introduction, andesitic metavolcanic arcs occur in the upper part of all of the crustal blocks identified by Windley and Garde (2009); Szilas et al. (2018) recently compiled an overview of their geochemical characteristics. Properties of the best-known arcs are shown in Table 1. The Greenlandic arcs also contain some of the oldest known epithermal mineralisation, including gold mineralisation and hydrothermal alteration in the Ivisaartoq metavolcanic belt (Polat et al., 2011), the Qussuk-Bjørneøen metavolcanic belt (Garde et al., 2012a), the Bjørnesund Supracrustal belt, the Godthåbsfjord-Ameralik belt, and the Tartoq Group, all described below. Epithermal gold mineralisation is an important, diagnostic constituent of modern island arcs. In high-grade Archaean terrains it can be difficult to distinguish between metamorphosed, deformed epithermal mineralisation as at Qussuk-Bjørneøen, and orogenic gold. For instance, in the Tartoq Group, a recent study of the initial gold mineralisation associated with hydrothermal arsenopyrite dated at $3.18-3.13 \mathrm{Ga}$ is not "orogenic gold" but part of the arc-related magmatism (Saintilan et al., 2020). Unspecified gold mineralisation also occurs in the Eoarchaean Isua supracrustal belt, particularly in the areas most strongly affected by later tectono-metamorphic events (Olsen and Grahl-Madsen, 1994).

\section{Ivisaartoq Metavolcanic Belt}

The Ivisaartoq metavolcanic belt at $64^{\circ} 45^{\prime} \mathrm{N}$ (Figure 1) contains deformed, metamorphosed pillow basalts with ocelli, cooling cracks and drainage cavities, volcanic breccias, picritic ultramafic flows with clinopyroxene cumulates, serpentinised ultramafic rocks, layered gabbros, and siliceous cherts (Chadwick 1990; Polat et al., 2007). The belt underwent two stages of calc-silicate metasomatic alteration between 3,075 and 2,963 Ma, namely epidotisation during seafloor hydrothermal alteration, followed by calc-silicate veins with diopside, garnet, amphibole, \pm vesuvianite associated with late shear zones. Because of the remarkable similarity in all respects Polat et al. (2007) and Ordóñez-Calderón et al. (2009) interpreted the geology and isotope-trace element chemistry of the Ivisaartoq belt and its distinctive mineralisation as a Mesoarchaean supra-subduction zone forearc, similar to that in Tethyan ophiolites in the eastern Mediterranean (Dilek and Flower, 2003).

\section{Qussuk-Bjørneøen Metavolcanic Belt}

The arc around $64^{\circ} 30^{\prime} \mathrm{N}$ in Godthåbsfjord (Figure 1) hosts a large epithermal gold occurrence (Garde et al., 2012a). The Qussuk arc contains a folded and metamorphosed, shallow-crustal argillic to advanced argillic alteration zone with a minimum strike length of $20 \mathrm{~km}$, embedded within the core of a less altered, bimodal andesitic-mafic metavolcanic belt. The leached and metamorphosed varieties of the andesite precursors contain abundant biotite, garnet and sillimanite, but very little or no feldspar. These rocks were originally mapped as pelitic metasediment (see also Schumacher et al., 2011). However, anomalously high contents of immobile trace elements including REEs, negative Eu anomalies (related to leaching of plagioclase), and anomalous $\mathrm{Ga} / \mathrm{Al}$ ratios show that up to $80 \%$ of the precursor rock was lost by leaching. The geochemical signature is best explained by near-surface boiling and dissociation of hydrothermal fluids into a barren, highly acidic phase and an enriched brine, as found in many modern circumPacific arcs (Simmons et al., 2005). Garde et al. (2012a) recorded in these altered rocks, zoned zircon grains, which contain igneous cores with high $\mathrm{Th} / \mathrm{U}$ ratios typical of primary volcanic zircons, yielding ages up to $c$. 3,070 Ma (Figure 4); the oldest nearby TTG rocks are c. 3,060 Ma in age (Garde et al., 2000). The surrounding zircon shells are strongly enriched in $U$ and Th, with REE patterns typical of hydrothermal zircons. Thin metamorphic rims yield ages of c. 3,000 Ma, contemporaneous with a regional thermal event recorded in most of the Akia terrane (see below). Schlatter and Christensen (2010) had previously shown that the intensity of alteration in the gold-mineralised rocks is highly variable, as is commonly the case in Phanerozoic epithermal gold deposits. The latter authors preferred an interpretation as "orogenic gold" related to the Palaeoproterozoic Ataneq fault $10 \mathrm{~km}$ away (Thøgersen et al., 2006; Garde et al., 2012a), although this is barren of gold.

\section{Storø Supracrustal Belt}

The Storø supracrustal belt is part of a complex zone of thrustimbricated and folded slices of supra- and infracrustal rocks of Eo-to Neoarchaean age (Friend and Nutman 2019 and older references therein) at the northern margin of the GodthåbsfjordAmeralik belt at around $64^{\circ} 30^{\prime} \mathrm{N}$ (Figure 1). It includes TTG orthogneiss, gabbro and anorthosite, mafic amphibolite, metasedimentary rocks, and altered garnet-rich lithologies. Dispersed gold mineralisation associated with quartz veins is hosted by supracrustal amphibolite in central Storø, in the vicinity of chemically altered rocks of volcanic origin (Scherstén et al., 2012; Szilas and Garde, 2013; Szilas et al., 2014, Szilas, 2016b). In spite of the geological complexity, it is widely agreed that the alteration of the aluminous and garnet-rich rocks was pre-metamorphic and that the gold was mobilised into its present location in the core of a late antiform (Szilas et al., 2016b). Arsenopyrite Re-Os and previously published zircon $\mathrm{U}-\mathrm{Pb}$ age data led Scherstén et al. (2012) to propose that the gold mineralisation formed at $2.71-2.64 \mathrm{Ga}$, i.e. somewhat younger than its host rocks. Szilas et al. (2016b) argued on geochemical grounds that the altered and subsequently metamorphosed rocks represent transported and weathered sediment derived from mafic volcanic rocks and that these rocks were unrelated to the gold mineralisation, although field observations suggest that the alteration took place in situ in volcanic rocks (Szilas and Garde, 2013). Irrespective of the source, mode and age of the gold mineralisation, there is consensus that the Storø supracrustal belt formed in a convergent plate tectonic setting, where continentally derived sediments were deposited along with arc-related mafic and intermediate volcanic rocks. 

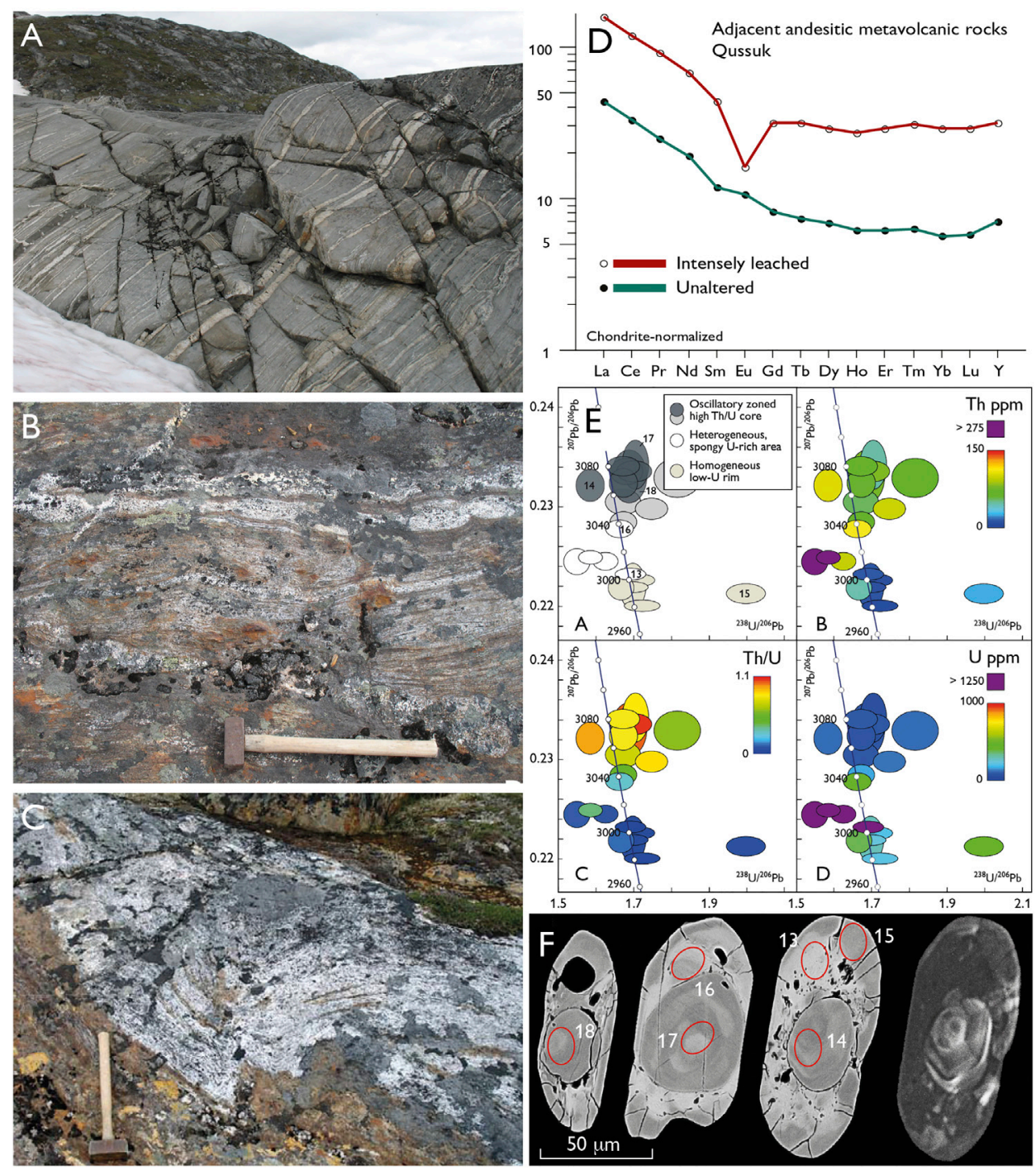

FIGURE 4 | Epithermal (pre-metamorphic) leaching of andesitic volcaniclastic rocks in the Qussuk-Bjørneøen metavolcanic belt north of Qussuk. (A) Unaltered meta-tuffaceous rock with partial melt seams. (B) Garnet-sillimanite-rich rock almost devoid of plagioclase, interpreted as a moderately leached volcaniclastic rock originally similar to that in (A). (C) Quartz-sillimanite rock interpreted as an altered andesitic volcaniclastic rock subjected to pre-metamorphic advanced argillic alteration. (D) REE diagrams of an unaltered volcaniclastic rock with a normal, LREE-enriched pattern (green) and a quartz-sillimanite rock strongly enriched in all REE except Eu, caused by leaching of up to $80 \%$ of the original rock and removal of all plagioclase, hence the negative Eu anomaly. (E,F) Zircon with three different age and geochemical components, comprising 1) original $\sim 3,075 \mathrm{Ma}{ }^{207} \mathrm{~Pb} /{ }^{206} \mathrm{~Pb}$ igneous cores with moderate $\mathrm{U}$ and Th contents and high Th/U ratios, 2) pre-metamorphic, hydrothermal zircon with abundant quartz inclusions and very high $U$ and Th contents and younger apparent ${ }^{207} \mathrm{~Pb} /{ }^{206} \mathrm{~Pb}$ ages (partially metamict and probably partially affected by early lead loss), and (3) rims with lower $U$ and Th contents, low Th/U ranges and yielding $\sim 3,000 \mathrm{Ma}{ }^{207} \mathrm{~Pb} /{ }^{206} \mathrm{~Pb}$ ages known from the regional metamorphism. See Garde et al. (2012a) for further details.

\section{Ameralik Supracrustal Belt}

The Ameralik supracrustal belt at $64^{\circ} 05^{\prime} \mathrm{N}$ in the Sermilik block (Figure 1) was mapped at a scale 1:100,000 (Rehnström, 2011), but it has not been described in detail. Szilas et al. (2015) made a geochronological and geochemical investigation of the belt. It is not a coherent unit but consists of numerous inclusions of amphibolite, ultramafic rocks, garnet-mica schists, sillimaniteand cordierite-bearing schists, quartzites and remnants of layered anorthosite complexes that are sheared and boudinaged with the adjacent TTG gneisses. The sillimanite-cordierite-bearing rocks and the quartzites were interpreted as metasedimentary rocks, but might also represent hydrothermally altered (leached) rocks of volcanic origin as documented at Qussuk (see Qussuk-Bjørneøen Metavolcanic Belt); notably Szilas et al. (2015) showed that several of the rocks recognised as of volcanic origin have been hydrothermally altered. The least-altered metavolcanic rocks have a narrow major-element compositional range with $\mathrm{SiO}_{2}$ contents between $48.0-51.2 \mathrm{wt} \%$, but Szilas et al. (2015) identified two different geochemical groups based 
on trace elements. Like many other belts described here, as pointed out in the geochemical review by Szilas et al. (2018), the two groups do not represent a single magmatic suite, because they contain rocks with different crustal and mantle source components (Figure 2), as also indicated by the large range of initial $\varepsilon \mathrm{Nd}_{2970 \mathrm{Ma}}$ values from 0.0 to +5.7 and the initial $\varepsilon \mathrm{Hf}_{(2,970 \mathrm{Ma})}$ values from +0.7 to +10.4 in the least-altered amphibolites (Szilas et al., 2015).

\section{Nunatak 1390}

As its name implies, Nunatak 1390 is a nunatak at $63^{\circ} 40^{\prime} \mathrm{N}$ in the Greenland ice cap in the Sermilik block, east-north-east of Sermilik-Figure 1 (Stendal and Scherstén, 2007; Scherstén et al., 2008; Szilas et al., 2012b). The nunatak contains a wellpreserved bimodal volcanic succession of mafic to ultramafic rocks, as well as associated acid volcanic rocks and granite intrusions. The nunatak was first described by Escher and Pidgeon (1976) and later mapped in detail by Stendal and Scherstén (2007), who established a relative stratigraphy; the thickness of the entire volcanic package is about $2 \mathrm{~km}$. Being only slightly to moderately deformed, the rocks show wellpreserved primary pillow lavas, finely laminated tuffites, ignimbrites (Figure 5), and relict vesicles in pillows and flows.

The lower half of the supracrustal package is dominated by deformed mafic pillow lavas and pillow breccias that are extensively altered and contain calc-silicate minerals, and cut by an E-W-trending swarm of 1-5 m-thick, gabbroic to noritic dykes. In the upper pillow lavas ultramafic greenstones and soapstones have been interpreted as intrusive sills. Above the upper mafic pillow lavas there is a ca 80 m-thick unit of felsic volcanic and pyroclastic rocks that include ignimbrites with recognizable fiammé textures; these rocks are cut by felsic dykes $(<1 \mathrm{~m})$ interpreted as feeders to higher felsic lavas in the pile. The felsic rocks are overlain by mafic flows and ash beds that are intercalated with ultramafic sills and mafic rusty layers containing sulfides and tourmalinites. The top $700-800 \mathrm{~m}$ of the sequence consist of finely bedded tuffs, which pass upwards increasingly to subvolcanic granite intrusions.

Geochemically the lower mafic-ultramafic rocks have whole rock compositions that plot along a well-defined tholeiitic trend (high $\mathrm{Fe} / \mathrm{Mg}$ series, Figure 2), whereas the felsic rocks, which are intercalated with tholeiites, form a loosely defined calc-alkaline group (low $\mathrm{Fe} / \mathrm{Mg}$ ) with an andesitic to dacitic composition. The tholeiites have $\mathrm{Nb} / \mathrm{La}$ ratios of $0.6 \pm 0.1(1 \sigma ; \mathrm{n}=9)$, whereas the felsic volcanics have a substantially lower ratio of $0.14 \pm 0.03(1 \sigma$; $\mathrm{n}=5$ ); the tholeiitic ratios are thus reminiscent of those of lower crust, whereas the low ratios of the felsic volcanics are typical of arc-related volcanic rocks. Based on the close spatial relationship between the felsic and tholeiitic rocks, Stendal and Scherstén (2007) considered that an arc setting was most plausible. They contended that the intercalation of the mafic and felsic rocks could by analogous to that of a modern arc system, reflecting input from volcanoes in the trench side (tholeiites) and calcalkaline rocks in an arc to back-arc.

\section{Grædefjord Supracrustal Belt}

The Grædefjord supracrustal belt, situated at $63^{\circ} 20^{\prime} \mathrm{N}$ on the southern side of Grædefjord in the Sermilik block (Figure 1), is
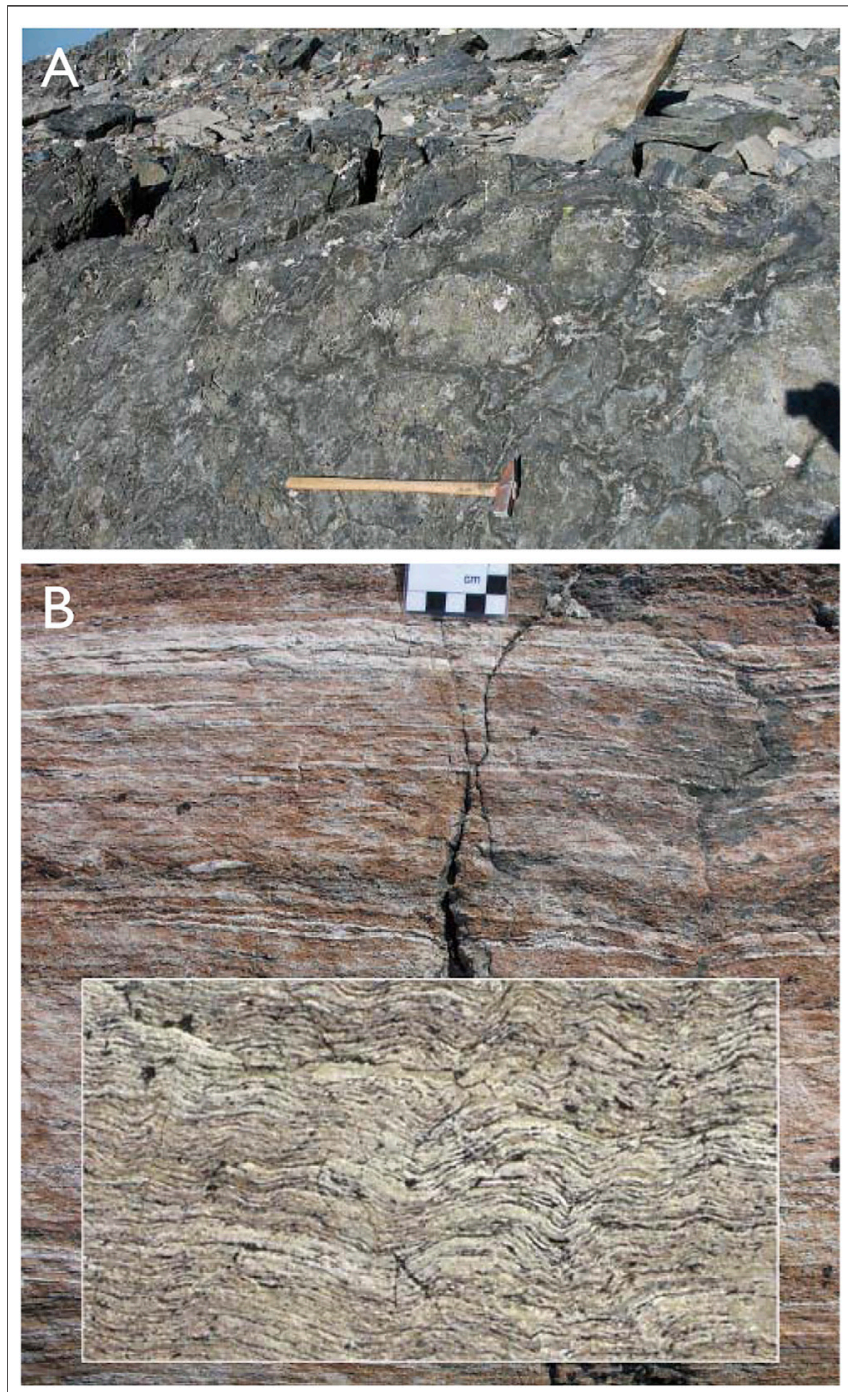

FIGURE 5 | Bimodal metavolcanic rocks on Nunatak 1390. (A) Pillow lavas in the upper pillow lava sequence. (B) Laminated felsic volcanic rock (ignimbrite). Inset: enlargement $\sim 5 \mathrm{~cm}$ wide. Hammer is $50 \mathrm{~cm}$ long. From Stendal and Scherstén (2007) with permission from the Geological Survey of Denmark and Greenland.

bimodal comprising about 50\% amphibolite (metabasalts) and 40-50\% leuco-amphibolite (mostly meta-andesite) together with minor ultramafic rocks and late granitoids (see later). The Grædefjord area is characterised by intense cataclastic and brittle-ductile mylonites (Dziggel et al., 2017). The degree of deformation varies throughout the supracrustal belt, being strongest toward the sheared contacts with the surrounding TTG gneisses. Toward the interior of the belt deformation is less pronounced and primary pyroclastic lithologies such as agglomerates, tuffs and volcanic breccias are preserved.

The supracrustal belt has a poorly constrained Sm-Nd and LuHf isochron formation age of $\sim 2,970 \mathrm{Ma}$, similar to that of the Fiskenæsset Complex (Szilas et al., 2013a). Whole rock geochemical data, which confirm the bimodal compositions inferred from field observations, define the two main groups 
that belong to different chemical differentiation series. The amphibolites have a tholeiitic (high $\mathrm{Fe} / \mathrm{Mg}$ ) affinity coupled with a moderately depleted incompatible trace element signature of $(\mathrm{La} / \mathrm{Sm}) \quad \mathrm{N} \sim 1)$ and weak negative $\mathrm{Nb}-\mathrm{Ta}$ anomalies of $\left(\mathrm{Nb} / \mathrm{Nb}^{*}=0.6-1.1\right)$, which plot above the mantle array in a $\mathrm{Th} / \mathrm{Yb}$ vs. $\mathrm{Nb} / \mathrm{Yb}$ Pearce diagram (Figure 2). In contrast, the leuco-amphibolites are calc-alkaline with andesitic compositions that show moderately enriched incompatible trace element signatures with $(\mathrm{La} / \mathrm{Sm})_{\mathrm{N}}=2.7-5.7$ and negative $\mathrm{Nb}-\mathrm{Ta}$ anomalies of $\left.\mathrm{Nb} / \mathrm{Nb}^{*}=0.01-0.45\right)$ that plot well within the arc-field on a $\mathrm{Th} / \mathrm{Yb}$ vs. $\mathrm{Nb} / \mathrm{Yb}$ Pearce diagram. Geochemical modelling suggests that the trace element variation of the leuco-amphibolites is due to mixing between basaltic mantle-derived magma and crust-derived felsic magma with at least $50 \%$ contribution from the latter. Hf-isotope constraints point to contamination with pre-existing continental crust that has an age of c. 3,250 Ma, a model that is underpinned by the preservation of coeval inherited zircons in local TTG gneiss. Ultramafic rocks of the Grædefjord supracrustal belt have platinum-group element (PGE) patterns that are similar to those of magmas generated from a high-degree melting of mantle, but they have relatively enriched trace element patterns. The rocks are interpreted to represent arc-related picrites or alternatively high degree partial melts of metasomatised subcontinental lithospheric mantle. Szilas et al. (2013a) concluded that the proposed mixing model for the Grædefjord supracrustal belt is comparable to that in modern continental subduction zone environments, where mixing and crustal contamination processes are univocally important. A possible difference may be the extent of crustal melting, which was higher in the Archaean due to a hotter Archaean sub-continental mantle, compared to that of modern arcs where assimilation of pre-existing continental crust is relatively more important.

\section{Bjørnesund and Ravns Storø (Ikkattup Nunaa) Supracrustal Belts}

The Bjørnesund and Ravns Storø supracrustal belts that crop out at $63^{\circ} \mathrm{N}$ just north of Frederikshåb Isblink (Figure 1) consist of upper amphibolite facies, andesitic metavolcanic rocks with prominent pyroclastic lapilli tuffs, agglomerate bombs and pillows (Andersen and Friend, 1973; Keulen et al., 2014, including a summary of previous work). The two belts belong to the same mafic volcanic sheet that was subsequently folded. Leuco-amphibolites in the Ravns Storø belt have a whole-rock Sm-Nd isochron age of 3,020 $\pm 78 \mathrm{Ma}$ and juvenile values of $\varepsilon \mathrm{Nd}_{(2,970 \mathrm{Ma})}$ of +2.1 to +3.5 and $\varepsilon \mathrm{Hf}_{(2,970 \mathrm{Ma})}$ of +3.5 to +4.3 (Szilas et al., 2012a), while Nutman et al. (2004) reported a SHRIMP zircon $\mathrm{Pb}-\mathrm{Pb}$ age of $2,908 \pm 13 \mathrm{Ma}$ for a volcanic sediment in the same supracrustal belt. The supracrustal belts were intruded by the anorthositic-gabbroic-ultramafic rocks of the Fiskenæsset complex (see below), by subhorizontal sheets of diorite, and later protoliths of the granodiorite-trondhjemite orthogneisses (Keulen et al., 2014) that make up about 75-85\% of the Archaean crust in West Greenland (Kalsbeek and Myers, 1973; Steenfelt et al., 2005).

The main regional deformation at Bjørnesund is associated with major folds (F2 in most literature), thrusts and shear zones.
Large-scale regional F2 folds throughout the entire area between Fiskenæsset and Frederikshåb Isblink (e.g., Myers, 1985) belong to a deformation event that moved from south (Paamiut area), north-eastwards (Bjørnesund region), to north-west (north of Fiskenæsset) between 2.86 and $2.83 \mathrm{Ga}$ (Keulen et al., 2011). The folding was associated with intrusion of granites in fold axial planes.

The Bjørnesund supracrustal belt is mineralised with gold, which represents an original arc-related mineralisation that was metamorphosed and variably remobilised. According to Kolb et al. (2013) thrusts and shear zones that were active during the main deformation event acted as pathways for fluids, which created interactions with the host amphibolites and transported the gold into the amphibolites. The gold accumulation is thought to have occurred during the intrusion of granites into the Bjørnesund supracrustal belt and during deformation associated with coeval thrusts and strike slip faults (Keulen et al., 2014). Metasomatic aluminous gneisses containing cordierite, garnet and sillimanite were generated during hightemperature hydrothermal alteration of the volcanic rocks (Schumacher et al., 2011; Schlatter and Stensgaard, 2014); these are difficult to distinguish from metamorphosed rocks that had already been altered in a surficial environment.

\section{Nigerlikasik Belt}

The Nigerlikasik metavolcanic belt at $62^{\circ} 05^{\prime} \mathrm{N}$ is the easternmost of three subparallel supracrustal belts in the Paamiut region of the Kvanefjord block (Figure 1). The entire sequence was metamorphosed at upper amphibolite facies and subjected to at least two stages of folding (Klausen et al., 2017). An E-W, $c$. $550 \mathrm{~m}$-profile shown in Figure 6 demonstrates that the belt consists of a mafic to ultramafic lower part and an intermediate to felsic upper part. From base to top the belt comprises: 1. Ultramafic serpentinites (hornblende \pm phlogopite \pm diopside \pm serpentinite/talc). 2. Mafic amphibolites, generally fine-grained, layered hornblende \pm biotite \pm plagioclase rocks. 3 . Intermediate, andesitic-dacitic, fine-grained, layered biotite \pm hornblende \pm plagioclase \pm quartz schists and gneisses. The surrounding felsic TTG gneisses are clearly intrusive into the supracrustal sequence. The Nigerlikasik belt has a minimum age of 2,930 Ma, constrained by zircon U-Pb ages of intrusive TTG-like sheets within the metavolcanic sequence (Klausen et al., 2017). Geochemically the Nigerlikasik belt records a distinct geochemical change in magmatism from tholeiitic (lower part) to calc-alkaline (upper part) (Figure 2). This indicates a fundamental change in the process of derivative magma generation, because it is not possible to link the two rock suites simply by magmatic differentiation. Klausen et al. (2017) interpreted the entire metavolcanic sequence in the framework of a single maturing island arc, with an initial tholeiitic stage characterised by more juvenile (mantlesourced) magmatism, followed by a differentiated calc-alkaline stage when crustal sources were involved in the generation of the andesite-dacite suite. The final stage of TTG intrusion was interpreted as a separate stage (unrelated to the andesite-dacite suite) of melt formation in the lower crust, which by that time 

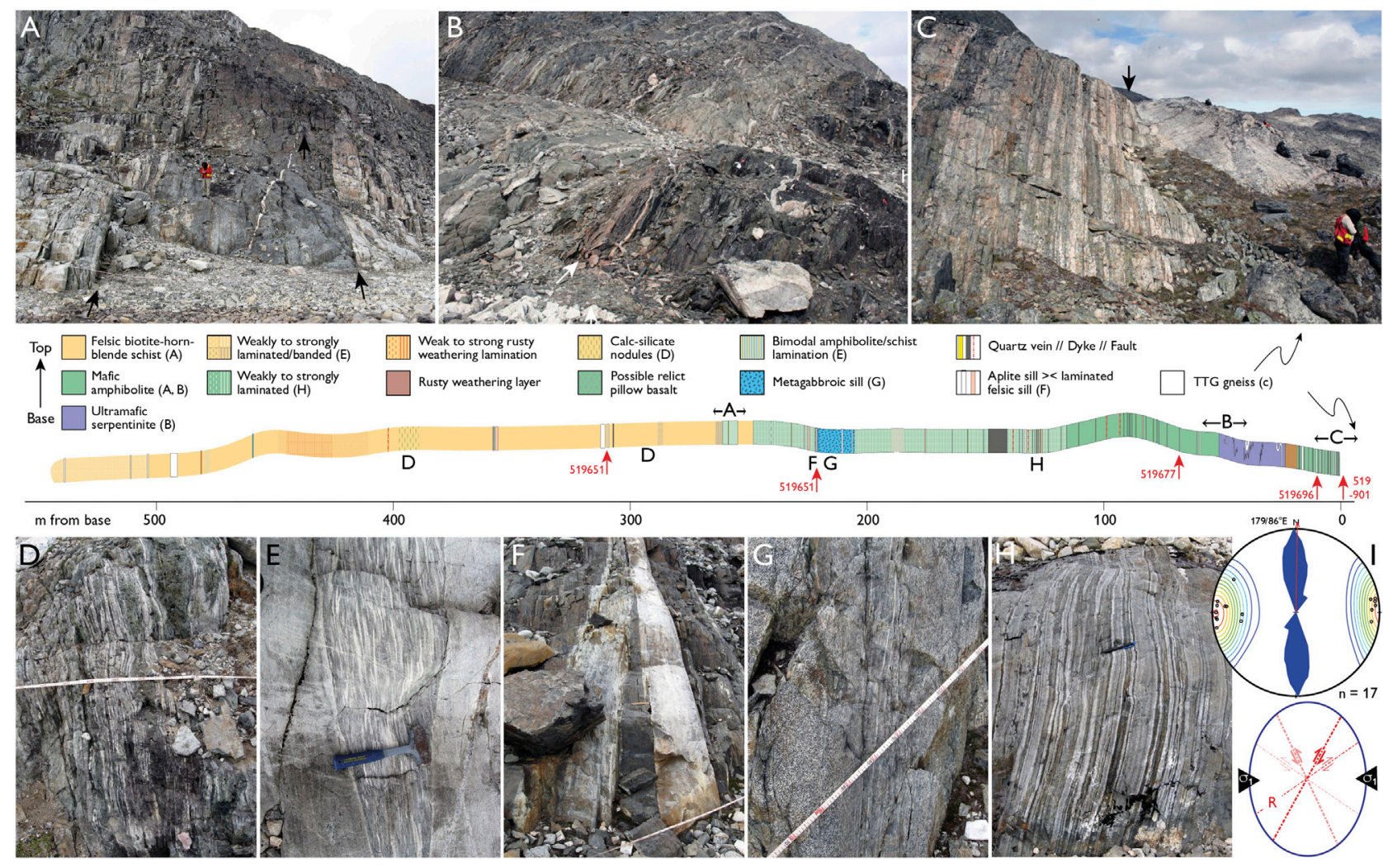

FIGURE 6 | Field relationships along a representative transect of the Nigerlikasik metavolcanic belt in the Kvanefjord block with mafic and calc-alkaline metavolcanic units. (A-C) Overview of main lithologies with important unit boundaries marked by arrows. (A) Amphibolite layer (dark) with biotite-hornblende schist (pale) on either side, interpreted as extrusive (left) and intrusive (right). Person for scale. (B) Contact between amphibolite (left) and darker serpentinite (right). (C) Contact between amphibolite and aplite (left) and coarse-grained TTG host. Person for scale. (D) Pale biotite-hornblende schist interbedded with boudinaged and darker serpentinite. (E) Biotite-hornblende schist with elongate, pale clasts of presumed pyroclastic origin. Hammer is $30 \mathrm{~cm}$ long. (F) Two different types of presumed intrusive felsic sheets inside amphibolites (left) biotite-hornblende schist and (right) aplite. (G) Rare coarser grained amphibolite interpreted to be a metagabbroic intrusion. (H) Layered amphibolite. Pen for scale. (I) Stereogram, poles to measured subvertical foliations or transposed bedding planes. See Figure 3 in Klausen et al. (2017) for further details.

would have been substantially thickened by magmatic accretion and might constitute a proto-craton.

\section{Tartoq Group}

The Au-mineralised Tartoq Group at $61^{\circ} 45^{\prime} \mathrm{N}$ (Higgins and Bondesen, 1966; Higgins, 1968; Appel and Secher, 1984; Evans and King, 1993) comprises greenschist-to granulite-grade, mainly mafic metavolcanic rocks with well-preserved subaqueous lava flows, basaltic pillows, andesitic lapilli tuffs, shallow crustal mafic sills and dykes, gabbroic rocks, and serpentinites that may have been derived from harzburgitic cumulates or from the mantle, as well as sedimentary banded iron formation; this combined rock assemblage closely resembles the lithological units that typically occur in oceanic crust (Szilas et al., 2013b). The mafic lavas have chondrite-normalised REE patterns and $\mathrm{Th} / \mathrm{Y}-\mathrm{Nb} / \mathrm{Yb}$ ratios indicative of an arc affinity when compared with modern island arcs (Figure 2). Nutman and Kalsbeek (1994) reported a SHRIMP zircon U-Pb age of 2,944 \pm 7 Ma for an intrusive TTG, which provides a minimum crystallisation age, while $\mathrm{Lu}-\mathrm{Hf}$ regression gives a model age of c. 3,189 $\pm 65 \mathrm{Ma}$ for the Tartoq Group (Szilas et al., 2013b). Saintilan et al. (2020) obtained Re-Os model ages of c. $3.18-3.13 \mathrm{Ma}$ from arsenopyrite in gold-sulphide-mineralised shear zones and interpreted the mineralisation as associated with arc volcanism (and thus likely originally epithermal), whereas Nutman et al. (2004) found detrital zircons as young as $2,842 \pm 6 \mathrm{Ma}$. The various latter data may indicate that the Tartoq Group contains significantly different age components.

Kisters et al. (2012) and Polat et al. (2016) described the postdepositional geological history of the Tartoq Group. It is interpreted as beginning with burial and subduction of supracrustal rocks, followed by exhumation and expulsion, and finally overprinting by transcurrent shearing. Most of the observed features comply with those occurring during hightemperature subduction and retrogresssion during exhumation at a modern convergent margin (see also van Hinsberg et al., 2018). Different from current subduction settings are the absence of high-P metamorphic rocks and the close spatial and temporal association between granitoid plutonism and the structural burial and return flow of the Tartoq Group, both of which are explained by a higher geothermal gradient than today in this Archaean subduction zone. Slab melting and the formation of granitoids at 
a relatively shallow depth in the subduction channel move the magmatic front to the forearc region of the convergent margin. The high geothermal gradient would have caused a higher volume of felsic melts and a weaker crust, enhancing the disintegration of the downgoing slab and thus producing a short-lived subduction event alternating with slab break-off and backstepping of the subduction front in a wide accretionary complex. This scenario was replicated by Polat et al. (2016) who made a convincing comparison between the accretionary Mesoarchaean Tartoq Group and the Upper Cretaceous Chugach-Prince William accretionary complex in Alaska, having formed by subductionaccretion processes.

\section{Magma Chambers and Layered Complexes in Island Arcs}

Both the lower and upper crustal sections of many Archaean cratons contain minor, but prominent and distinctive layered intrusions that consist predominantly of megacrystic, calcic anorthosites (often chromite-layered) and anorthositic leucogabbros that are typically accompanied by gabbros, melanogabbros, dunites and harzburgites. These complexes are often amazingly well-preserved, and contain important diagnostic evidence for their mode of origin and tectonic environment. There is at least $500 \mathrm{~km}$ strike-length of such anorthositic complexes in the West Greenland NAC. Yet, they are surprisingly poorly referenced in many papers on Archaean crustal evolution. Overall, it is widely considered that these intrusions were generated in oceanic island arcs and derived from sub-arc hydrous mantle sources.

\section{Fiskenæsset Complex}

West Greenland contains the most extensive and best-known examples of these layered intrusions, of which the Fiskenæsset complex at $63^{\circ} 20^{\prime} \mathrm{N}$ (Figure 1) is the largest and most complete. Its original maximum stratigraphic thickness is close to $540 \mathrm{~m}$. The current tectonic thickness reaches $2 \mathrm{~km}$ and some folded layers have an exposed length of at least $30 \mathrm{~km}$ (Myers 1985). Although isoclinally and tightly folded three times, metamorphosed up to granulite facies in some areas and commonly retrogressed to high amphibolite facies, the complex has a remarkably well-preserved magmatic stratigraphy, which from top to bottom is: upper gabbro, chromite-layered anorthosite with megacrystic plagioclase $\left(A n_{75-95}\right)$, upper leucogabbro, middle gabbro, lower leucogabbro, ultramafic unit (peridotite, dunite, hornblendite), lower gabbro; the weighted lithological average is leucogabbro (Myers, 1985). Excellently preserved primary structures include hundreds of mineral/size-graded layers, cumulate textures, scour channels and trough layering. The leucogabbros are characterised by a cumulate plagioclasehornblende assemblage in which plagioclase megacrysts may reach $30 \mathrm{~cm}$ across, and undeformed chromitite layers in anorthosites are up to $20 \mathrm{~m}$ thick. The Fiskenæsset complex has a Sm-Nd age of 2,973 $\pm 28 \mathrm{Ma}$, and a $\mathrm{Pb}-\mathrm{Pb}$ isotope regression age of 2,945 $\pm 36 \mathrm{Ma}$ (Polat et al., 2010). Best-preserved anorthosites and leucogabbros contain zircons with a weighted mean $\mathrm{U}-\mathrm{Pb}$ age of 2,936 $\pm 13 \mathrm{Ma}$, which provides a minimum crystallisation age of the complex (Souders et al., 2013), or 2,973 $\pm 28 \mathrm{Ma}$ (Polat et al.,
2010), or 2,985 Ma (Hoffmann et al., 2012). Huang et al. (2012) demonstrated that the complex is characterised by depletions of high field strength elements (HFSE; $\mathrm{Nb}, \mathrm{Ta}, \mathrm{Zr}$, and $\mathrm{Hf}$ ) relative to Th, U, LREE and LILE (Rb, Ba), as well as enrichments of Sr and Pb relative to MREE, which are consistent with generation in an oceanic island arc. They also showed that abundant magmatic hornblende, the high anorthite content of plagioclase, and negative anomalies of $\mathrm{Nb}$ in hornblende are collectively consistent with a sub-arc, hydrous, parental liquid of high-alumina basalt derived from a mantle source (see also, e.g., Hoffmann et al., 2012; Souders et al., 2013; Polat et al., 2015).

The Fiskenæsset complex was emplaced into island-type volcanic rocks (now amphibolites) at 2.97-2.95 Ga (Polat et al., 2010; Keulen et al., 2010), intruded by voluminous tonalites at 2,863 \pm 10 and c. 2,802 Ma (Friend and Nutman, 2001; Steenfelt et al., 2005; Hoffmann et al., 2012), and likely underwent collision with other arcs and continental blocks in the late Neoarchaean. A characteristic and diagnostic feature of the Fiskenæsset complex is the presence over hundreds of kilometres of spectacular zones with a remarkable metasomatic assemblage with inter alia sapphirine, ruby, kornerupine, phlogopite, pargasite, enstatite, and red spinel-see Figure 7. The ruby and other aluminous phases were formed by metasomatic reactions at the contacts between the anorthosite and ultramafic rocks (Herd et al., 1969; Appel and Ghisler, 2014; Keulen et al., 2014; Smith et al., 2016; Keulen et al., 2020). The deformation and crustal thickening associated with early thrusting, subduction, and collision in the Fiskenæsset region gave rise to large-scale double and triple fold interference patterns and broadly synchronous amphibolite-granulite facies metamorphism (Windley and Garde, 2009).

\section{Other Anorthositic Complexes}

Many smaller anorthosite-leucogabbro-gabbro-ultramafic complexes lack the diagnostic stratigraphy, chromitites and associated distinctive sapphirine-bearing rocks of the Fiskenæsset complex, and thus are considered to be derived from separate island arcs. Several were summarised by Windley and Garde (2009). These include.

A. The Naajat Kuuat complex in the eastern Tasiusarsuaq terrane (Figure 1), which has been subjected to the most detailed geochemical and isotopic study of all the anorthositic complexes in Greenland (Hoffmann et al., 2012).

B. The Buksefjorden and Tre Brødre complexes in the Tasiusarsuaq terrane (Friend et al., 1987).

C. Ivittuut, South Greenland. This up to $15 \mathrm{~km}$ wide and $55 \mathrm{~km}$ long anorthosite-gabbro complex was defined entirely by mapping innumerable anorthosite-gabbro inclusions in the host TTG orthogneisses (Berthelsen and Henriksen, 1975). The original igneous complex was invaded passively by voluminous protoliths of the gneisses, leaving the inclusions in their original magmatic stratigraphic positions; this illustrates the remarkable degree of preservation of original material that is possible in the Earth's deep crust, and emphasises the importance of not neglecting the role of inclusions in TTG gneisses. 

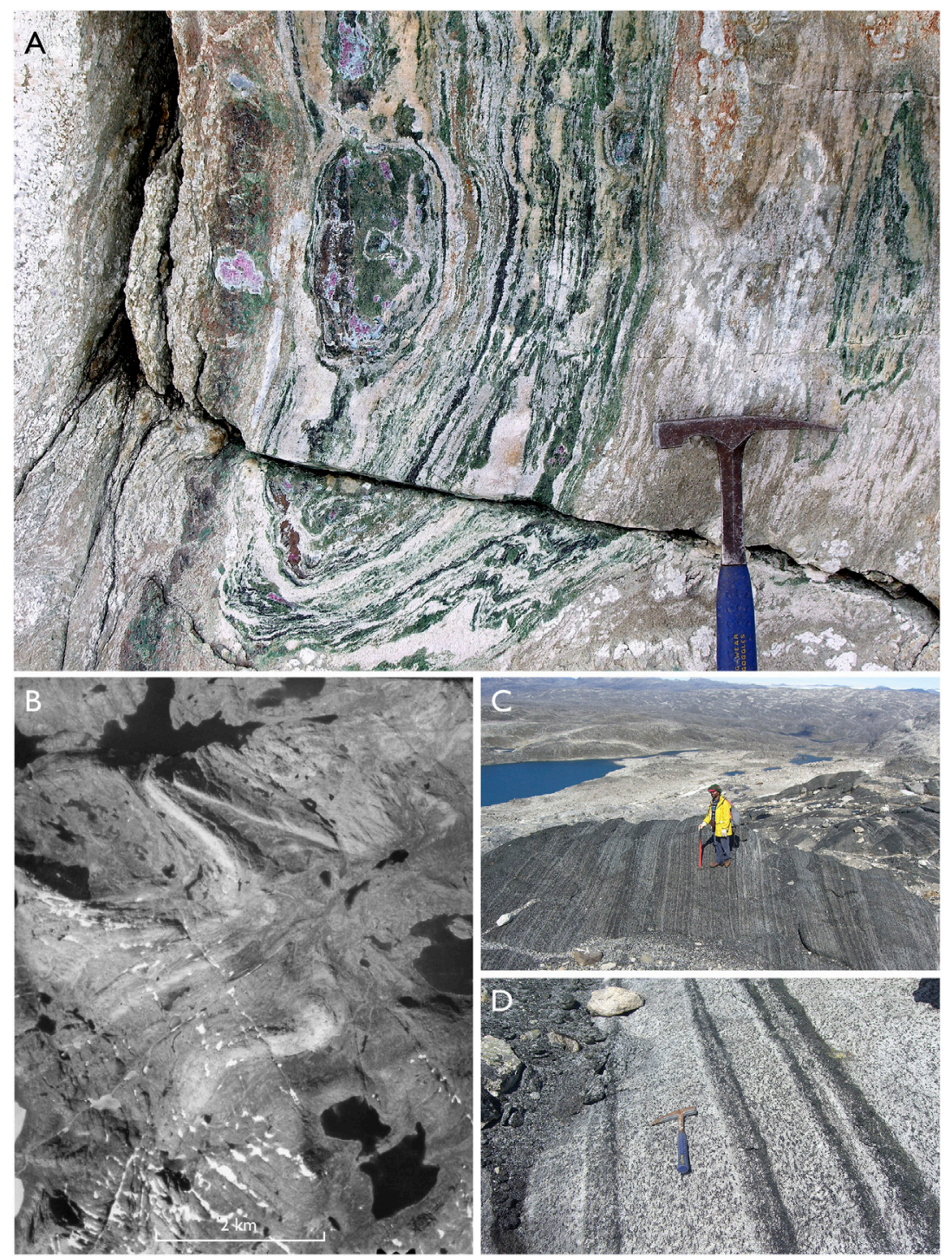

FIGURE 7 | Four photos showing different aspects of the Fiskenæsset complex. (A) Folded layers with blue sapphirine, ruby corundum rimmed by white plagioclase, green pargasite, black chromite, brownish red rutile, phlogopite, enstatite, gedrite, and white plagioclase-rich layers. Vertical face, Pequineq. (B) Oblique aerial photo showing two white anorthositic layers in grey amphibolite facies gneisses. Note prominent F3 folds. The main anorthositic layer is up to 2 km wide. Angnertussoq. (C) Layered sequence with individual layers of hornblendite, hornblende-bearing melagabbro and gabbro. Note the wide anorthositic layer in grey gneiss in the background. Majorqap Qaava. (D) Cumulate wide layers of hornblende anorthosite-leucogabbro and thin layers, which in places grade upwards to the left from basal hornblendite to tops of hornblende gabbro. Majorqap Qaava.

D. The Fiskefjord block contains a major folded layered complex, which comprises gabbroic and noritic rocks, dunitic cumulates and amphibolites (Garde, 1997; see below).

E. A conspicuous isolated anorthosite mountain called Fuglefjeldet occurs at the south-eastern boundary of the Fiskefjord block on the eastern side of the Qussuk peninsula.

\section{Dunitic Bodies in the Fiskefjord Block}

The south-western part of the Fiskefjord block contains several kilometre-sized lenses of ultrabasic rocks comprising peridotite, dunite and occasional layered chromitite. They are older than the regional TTG orthogneisses and mostly associated with layered metagabbroic and noritic rocks; a few are isolated enclaves in orthogneiss. Some contact zones are jumbled mixtures of ultrabasic rocks, amphibolite and orthogneiss. The dunitic component of the Seqi body (Figures $\mathbf{1}$ and 8) is highly refractory $\left(\mathrm{Fo}_{91-93}\right.$; Szilas et al., 2018). The dunitic bodies may represent residual upper mantle like the nearby kimberlite xenoliths (Bernstein et al., 1998; Bernstein et al., 2007), but their common association with metagabbros suggests they are more likely basal parts of layered complexes as indicated by their chromite compositions and platinum-group element patterns (Garde 1997; Guotana et al., 2018; Szilas et al., 2018). The 

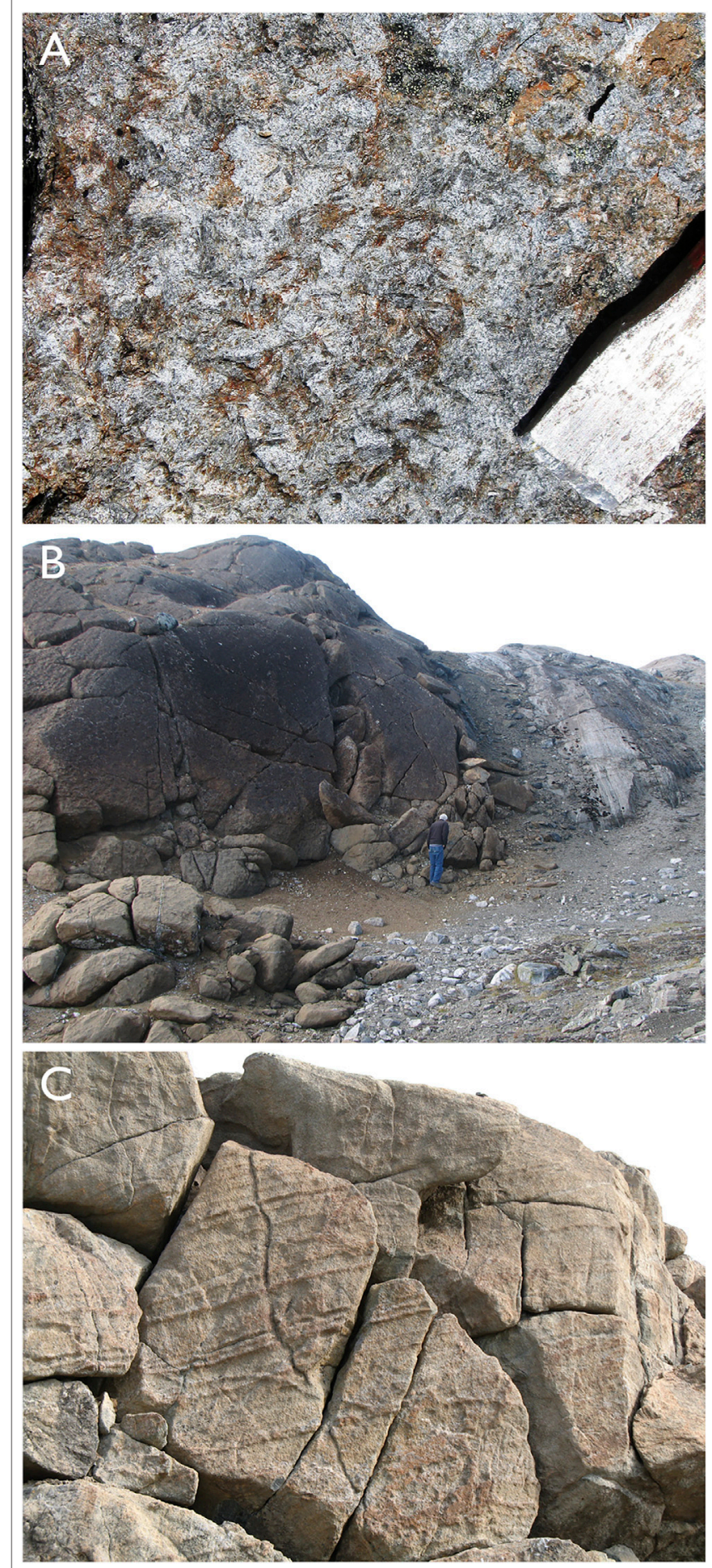

FIGURE 8|Ultrabasic rocks. (A) Pseudo-spinifex, garbenschieferlike, partial metamorphic recrystallisation of olivine to chlorite in dunite on the south coast of Kvanefjord (Figure 1); tip of chisel $2 \mathrm{~cm}$ wide. $\mathbf{( B , C ) ~ S e q i ~ d u n i t e ~ b o d y ~ i n ~ t h e ~ F i s k e f j o r d ~ b l o c k . ~ ( B ) ~ M a s s i v e ~}$ appearance of dunitic rocks and contact to younger TTG orthogneisses right. Person for scale. (C) Rare compositional layering in harzburgitic-dunitic rocks. Exposure $\mathbf{C} 2 \mathrm{~m}$ high. dunitic bodies are clearly not metamorphosed komatiites and do not yield support for plume or sagduction models.

\section{The Norite Belt in the Fiskefjord Block}

About 75 noritic intrusions $\sim 3.0$ Ga old with hybrid margins to their hosts occur in the northern Fiskefjord block, and related post-kinematic diorites farther south (Secher 1983; Garde 1991; Garde et al., 2013b; Waterton et al., 2020). The very variable geochemistry of these highly unusual rocks with high $\mathrm{Ni}$ and $\mathrm{Cr}$ contents suggests derivation from ultramafic magmas contaminated with $30 \%$ TTG material. They are unrelated to the older mafic-ultramafic complexes and difficult to explain, since the crustal evolution of the Fiskefjord block up to $3.0 \mathrm{Ga}$ was normal for the NAC. Origins by crustal thinning and extraterrestrial impacting have been suggested (see below).

\section{Evidence of Neoarchaean Collision Tectonics Collision Between the Godthåbsfjord-Ameralik Belt and the Tasiusarsuaq Terrane (Sermilik and Bjørnesund Blocks), and High-Pressure Metamorphism}

New evidence of extensive high-pressure metamorphism (Dziggel et al., 2014, 2017; Friend and Nutman 2019; Nutman et al., 2020) has reinforced the importance of collisional tectonics in the boundary region between the Godthåbsfjord-Ameralik belt and the Sermilik block (McGregor et al., 1991), supplementing lowpressure metamorphism interpreted by Wells (1979) as a result of injection of voluminous tonalitic magma into the middle crust. Prior to the final assembly between ca. 2,720-2,700 Ma (Nutman and Friend 2007; Dziggel et al., 2014; Dziggel et al., 2017; Dziggel, 2019), the structurally upper Tasiusarsuaq terrane underwent a prolonged period of medium- and high-pressure granulite facies metamorphism from ca. 2,800 Ma, which terminated in nearisobaric cooling and amphibolite facies reworking (Crowley 2002; Kolb et al., 2012; Dziggel et al., 2012; Dziggel et al., 2014; Dziggel et al., 2017). An excellent explanation of the history of the terrane concept in the Godthåbsfjord region and how it solved controversies in the 1980s between field observations and geochronological data is by Friend and Nutman (2019).

The Tasiusarsuaq terrane (Sermilik block, Figure 1) extends from the southern Nuuk region at Ameralik fjord all the way southward to Frederikshåb Isblink (Figure 1) and comprises TTG gneisses with intrusion ages of 2,880-2,860 Ma (Friend and Nutman 2005a; Næraa and Scherstén 2008). Geochronological data suggest that a significant earlier crust-forming event took place at around 2,920 Ma (Schiøtte et al., 1989; Kokfelt et al., 2011). McGregor and Friend (1992) recognised crustal tilting in the present Bjørnesund block and reported a rare prograde amphibolite to granulite facies boundary in inner Bjørnesund.

Dziggel et al. (2017) described deep-crustal granulite-facies rocks in the central Tasiusarsuaq terrane as ductile fold nappes like those in the orogens of the Grenville and Himalayas. The interpretation by Dziggel et al. (2017) was based on the estimated 
thickness of crust in the Neoarchaean $(\geq 60 \mathrm{~km})$, an apparent extrusion of deep-crustal nappes into the middle crust, and the evidence for contemporaneous underplating of cool and older continental crust, as suggested by McGregor et al. (1991) for the Godthåbsfjord region. Dziggel et al. (2019) argued that deformation of the Tasiusarsuaq terrane evolved from initial accretion to terminal continent-continent collision.

\section{Evidence of Collision in the Kvanefjord Block}

The Kvanefjord block was studied by McGregor and Friend (1997), Friend and Nutman (2001) and Nutman et al. (2004) who proposed several new tectono-metamorphic terranes (the Sioraq, Paamiut, Neria and Sermiligaarsuk blocks in their terminology).

Using published maps and subsequent observations, Windley and Garde (2009) re-examined the regional distribution of amphibolite facies, granulite facies and amphibolite facies rocks retrogressed from granulite facies within the Kvanefjord block and showed that the region can be viewed as one contiguous crustal segment of prograde amphibolite to granulite facies rocks, overlain by a major fold nappe, the Neria nappe, which was thoroughly retrogressed from the granulite facies and refolded by younger, upright folds. In contrast to early, recumbent isoclinal folds in other areas, which document horizontal tectonics during the crustal accretion, the proposed nappe affected rocks that had already been metamorphosed at granulite-facies conditions. It may well constitute evidence for collisional tectonics, comparable to that described from the Sermilik block farther north.

\section{New Crustal Accretion Models for the Fiskefjord Block}

Kirkland et al. (2018) proposed a new Meso-/Neoarchaean orogenic cycle in the north-western Fiskefjord block based on zircon geochronology of thin intercalations of homogeneous quartzo-feldspathic sheets in metavolcanic rocks. The model inferred complete denudation, a new regional unconformity, formation of a younger series of metavolcanic rocks than that established by previous workers and a second phase of granulite facies metamorphism after $\sim 2.8 \mathrm{Ga}$, see Discussion.

Yakymchuk et al. (2020) examined static partial melting of mafic rocks at four localities in the same region. They dated the partial melts to 3,010-2,990 Ma and modelled partial melt compositions in these rocks and compared them to the compositions of the regional TTG gneisses. Their modelling was consistent with an apparent, unusually high geothermal gradient of $>1,050^{\circ} \mathrm{C} / \mathrm{GPa}$ at around $3.0 \mathrm{Ga}$, implying thin crust. Along with the static metamorphism this prompted them to propose a non-uniformitarian, "stagnant lid" model (Sizova et al., 2015) with generation of TTGs from melting of coeval lower-crustal basic rocks without subduction; they also noted widespread regional evidence of early zircon lead loss. They expressed caution about their interpretation due to limitations in their modelling and a rather imperfect geochemical match of their modelled melt compositions with the regional TTG gneisses.

\section{The Maniitsoq Structure}

The most important but also the most controversial discovery in the northern Fiskefjord block is the $3.0 \mathrm{Ga}$ Maniitsoq impact structure, which occupies most of its northern part including the study area addressed in New Crustal Accretion Models for the Fiskefjord Block. (Figures 1 and 9; Garde et al., 2012b; Garde et al., 2013a, Garde et al. 2013b; Scherstén and Garde, 2013; Garde et al., 2014; Keulen et al., 2015). This structure comprises several anomalous, crustal-scale features (Table 2) which have recently given rise to different interpretations. The Finnefjeld domain 35 by $50 \mathrm{~km}$ large in the centre of the structure, consists of mechanically mixed cataclastic material, first described by Berthelsen (1962). The norite belt, which is not cataclastic, is located just east of this domain. The melt zone surrounding the Finnefjeld domain (Figure 1) contains evidence of direct melting of K-feldspar and biotite and in places localised bulk melting of felsic orthogneiss, besides further cataclasis and widespread, intense hydrothermal alteration in some parts. A minimum age from intensely altered zircon in the eastern part of the structure gave a hydrothermally reset $\mathrm{U}-\mathrm{Pb}$ age of 3,000.9 \pm 1.9 Ma (Scherstén and Garde, 2013).

The Maniitsoq structure is interpreted as the lower-crustal expression of a giant extraterrestrial impact structure with a surface diameter of $\sim 500 \mathrm{~km}$, estimated from iSALE impact modelling (Figures 9D-F; Trowbridge et al., 2017). Direct (shock) melting of $\mathrm{K}$-feldspar and biotite requires an extremely rapid and short-lived temperature excursion to temperatures not attainable by endogenic crustal processes $\left(>1,300\right.$ and $>1,400^{\circ} \mathrm{C}$, respectively) and signifies an extraterrestrial impact (French and Koeberl, 2010). Whereas unequivocal shock lamellae in quartz have not been preserved, shock lamellae in zircon were described by Garde et al. (2019). Glikson (2013) recorded the Maniitsoq structure as the oldest known impact structure on Earth. Because of its large size and deep depth of preservation it constitutes an important target for studies of impact processes approaching those that shaped the outer Earth during the 3.85 Ga Late Heavy Bombardment.

\section{A Relict Suture Between the Fiskefjord and Maniitsoq Blocks}

Windley and Garde (2009) placed their tectonic boundary between the Fiskefjord and Maniitsoq blocks where a metamorphic facies change and previous age determinations suggest a major break, namely a $2.5 \pm 0.2$ Ga metasedimentary ${ }^{87} \mathrm{Sr} /{ }^{86} \mathrm{Sr}$ whole-rock age on Hamborgerland (Kalsbeek and Hansen, 1989), a metamorphic zircon age of 2,738 \pm 6 Ma near Maniitsoq (Friend and Nutman, 1994), and detrital and metamorphic zircon ages of 3,180-2,700 and 2,550 Ma respectively, of a metasedimentary gneiss at Kangerluarsuk (Garde et al., 2000). With new zircon ages of $2,560 \mathrm{Ma}$ from migmatite leucosomes about 5 and $30 \mathrm{~km}$ north-west of Kangerluarsuk, respectively, Dyck et al. (2015) proposed a S-dipping suture (a palaeo-subduction zone, Figure 10) along Kangerluarsuk fjord near the proposed block boundary (Figure 1). This zone includes medium-to high-pressure, kyanite-bearing rocks, and disrupted lenses of dunite surrounded by metasomatic corundum-bearing rocks, 

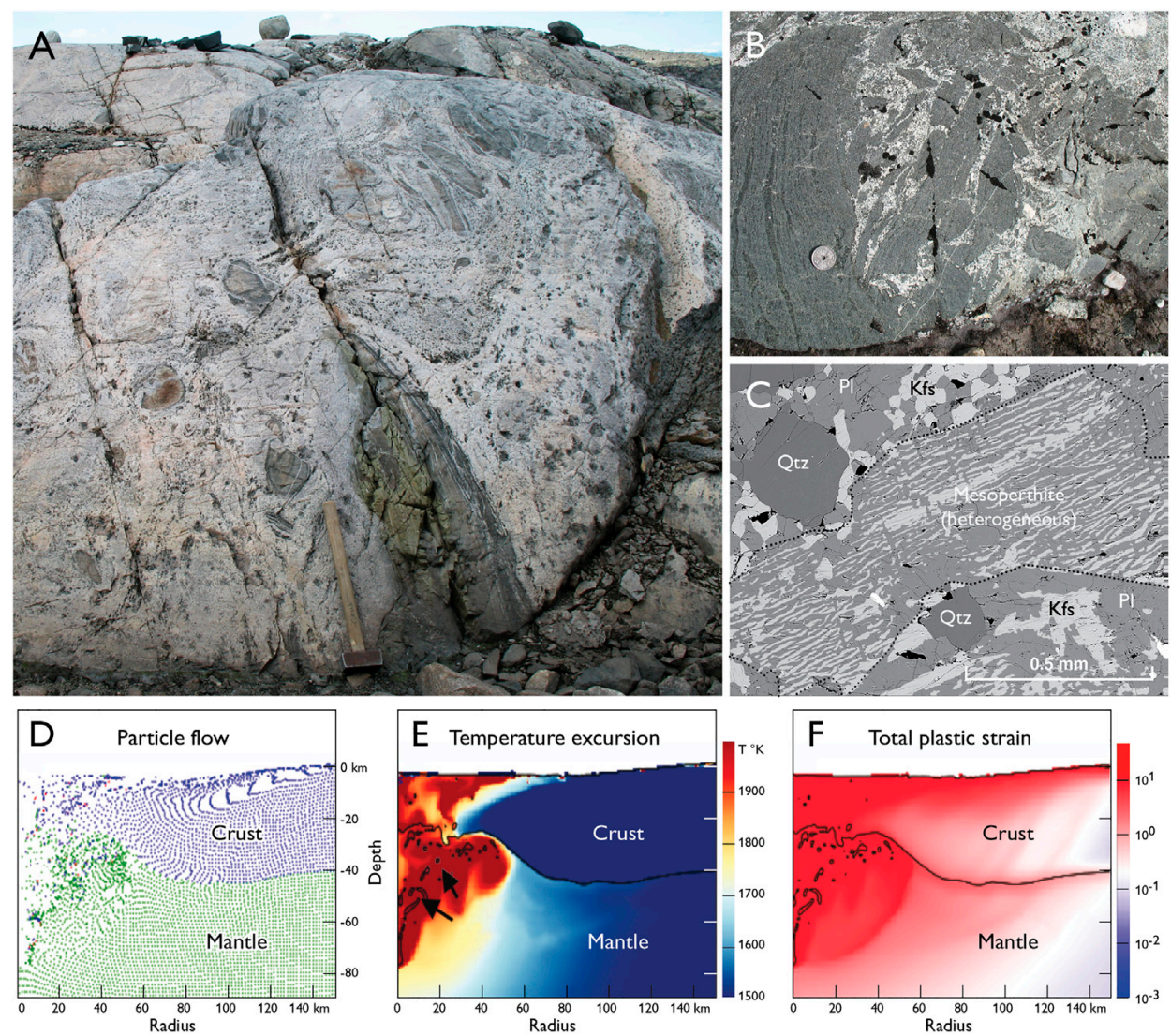

FIGURE 9 | Salient features and iSALE modelling of the proposed Maniitsoq impact structure. (A) Brecciated and hydrothermally altered orthogneiss-amphibolite complex in the eastern. Maniitsoq structure, interpreted as a result of impact-induced brecciation by seismic shaking and crustal-scale hydrothermal convection in the now deeply exhumed structure from the front page of Meteoritics \& Planetary Science 48, vol. 8. (B) Example of deep-crustal brecciation and cataclasis. Brecciated amphibolite enclave with hairline cracks left and fragments right, drawn off toward the right with a locally derived granitic matrix (Garde et al., $2012 \mathrm{~b}$; Figure 3E). (C) Heterogeneous ternary feldspar grain (now mesoperthite) in granitic gneiss interpreted as a poorly mixed, feldspar melt of K-feldspar and sodic plagioclase. Note variable proportions of K-feldspar and plagioclase and internal zones of almost pure K-feldspar and plagioclase. Southern Melt zone of the Maniitsoq structure (Keulen et al., 2015; Figure 6B). (D-F) Results of iSALE modelling of a Maniitsoq-like impact structure 1,495 s after impact (Trowbridge et al., 2017). (D) Tracer particle result. Blue: crust. Green: mantle. Red: remnant projectile. (E) Temperature plot in ${ }^{\circ} \mathrm{K}$. Irregular shaped objects within the high-temperature zone of the mantle are crustal material. (F) Total plastic strain result.

suggesting tectonic extrusion along the proposed suture. Adjacent anthophyllite-gedrite-bearing amphibolites most likely represent hydrothermally altered tholeiitic lithologies similar to those containing semi-precious ortho-amphibole gemstones near Nuuk (Appel and Jensen, 1987). Dyck et al. (2015) also described a lithological change and different stream sediment compositions across the tectonic boundary, and a gravity high, from which they proposed a new tectonostratigraphic unit, the Majorqaq belt, between the Fiskefjord and Maniitsoq blocks (Figure 1). This belt supposedly constitutes the last phase of amalgamation between the Fiskefjord and Maniitsoq blocks.

The belt probably contains several unrelated imbricated components, given metamorphic zircon ages of $\sim 2,815 \mathrm{Ma}$ near Kangerluarsuk and $\sim 3,010 \mathrm{Ma}$ just north of Maniitsoq (Garde et al., 2000; Yakymchuk et al., 2020). The metamorphic history of the Majorqaq belt indicates a clockwise P-T evolution, interpreted as evidence for rifting and subduction, rather than over-accretion that would produce an anti-clockwise evolution (Dyck et al., 2015). The inferred $\sim 2.56 \mathrm{Ga}$ subduction is contemporaneous with the intrusion of the crust-derived Qôrqut granite complex in the Nuuk region (Nutman et al., 2010; Næraa et al., 2014); Dyck et al. (2015) suggested that dehydration fluids from the subducted oceanic plate triggered lower-crustal remelting that produced the granite. In summary, the southern boundary of the Majorqaq belt constitutes a strong candidate for Neoarchaean plate tectonic subduction and collision, essentially undisturbed by later crustal events.

Xenocrystic zircons in a $557 \mathrm{Ma}$ kimberlite on the southern side of the Majorqaq belt yielded a wide range of Eo-to Neoarchaean ages that were interpreted as lithospheric growth by tectonic stacking after the assembly of the NAC (Gardiner et al., 2020). 
Table 2 | Salient features of the proposed Manitsoq impact structure

Explanation

References

Finnefjeld domain

Direct melts of K-feldspar and biotite

Micro-cataclasites

K-feldspar veins lining microcataclasites

Fracture cleavage

In-situ breccias

Planar microstructures in zircon

Hydrothermal alteration to $3.0 \mathrm{Ga}$

'Norite belt'
Bulk melts of former TTG gneisses

Crustal-scale cataclastic and mechanically mixed body $35 \times 50$ km in outcrop size; not an Berthelsen (1962); Garde et al. (2012b, Garde et al. 2014, Figure 8) intrusion. Average composition lower crust including dispersed material from mafic

metavolcanic component.

Observed in granitic gneisses and with micro-cataclasites. Note: direct melting is a shock- Scherstén and Garde (2013, Figure 2); Garde et al. (2014): Keulen et al. (2015) induced, instantaneous phase transformation from mineral to melt without chemical reaction

with other phases.

Widespread micro-cataclastic zones akin to pseudotachylytes, formed in situ. Interpreted Garde et al. (2012b, Figures 4a, 5); Bridgwater et al. (1976) as reflecting numerous pulses of intense, deviatoric pure shear stress. First described as

"grey dykes" in 1976 in NW Godthåbsfjord. See also Garde and Klausen (2016).

Veins of K-feldspar lining micro-cataclasites, crystallised from K-feldspar melts and

undeformed. Interpreted as direct melts formed during cataclasis and separated from the

solid, micro-cataclastic constituents.

Bulk melting of older anatectic orthogneiss with new magmatic mineral textures. Alanngua Garde et al. (2014, Figures 3a, 4a)

area and northern inner Fiskefjord, bordering the Finnefjeld domain.

Regionally pervasive, subvertical fracture cleavage spaced at 1-2 cm. May represent _ Garde et al. (2012b. Figure 3b)

incipient percosive subvical fracture clavage spaced at 1-2 cm. May represt

but never from deep-crustal tectonic deformation.

Mainly in mafic rocks. Matrix ductilely emplaced from adjacent rock or local melt. Example in Berthelsen (1960, photos and sketches of outcrops). Garde et al. (2012b, Figure 3a; Yakymchuk et al. (2020) but with another interpretation. Note: in-situ cataclasis and brittle Garde et al. 2014, Figure 8); Yakymchuk et al. (2020, Figure 2a)

fracturing in the lower crust requires very high deviatoric stress not attained during tectonic deformation.

Regional curvilinear deformation pattern Metavolcanic belts SE of the Finnefjeld gneiss and the Melt zone displaying a striking curvilinear pattern, superimposed on normal multiple fold patterns.

in, e.g., the Vredefort and Sudbury impact structures and indicative of shock

metamorphism. Note: quartz microstructures described by Garde et al. (2012) are poorly preserved and not diagnostic.

Very widespread, very intense and commonly associated with brecciation of mafic rock components. Not studied in detail. Prior to 2012 interpreted as endogenic metamorphic retrogression from granulite facies.

Coincidence of radiometric ages close A highly unusual regional preponderance of 3.0 Ga and slightly younger zircon U-Pb ages Garde et al. (2014, Table 1); Scherstén and Garde (2013); Gardiner et al. (2019);

in TTG orthogneisses and crustal melts, including reset ages. Note: this regional pattern of Yakymchuk et al. (2020)

radiometric ages has not yet been fully understood.

An elongate field of $\sim 75$ generally undeformed noritic intrusions wrapping around the Garde et al. (2012; Garde et al. 2013b)

eastern side of the Finnefjeld complex.

Inclined, undeformed, sill-like dioritic bodies. Mg-rich dioritic compositions with very high Cr Garde (1991); Garde et al. (2012b)

and Ni contents. Possible geochemical impact signature. Hybrid intrusive margins suggest

emplacement at high temperature. Note: no evidence of extension during emplacement.

First described in 2012 as a potential primary impact-related feature, but possibly related to Garde et al. (2012b)

the subsequent hydrothermal alteration. 


\section{N}

1. Subduction initiates

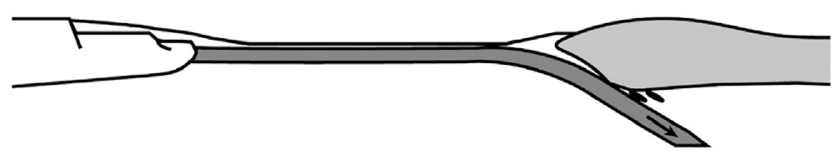

2. Convergence

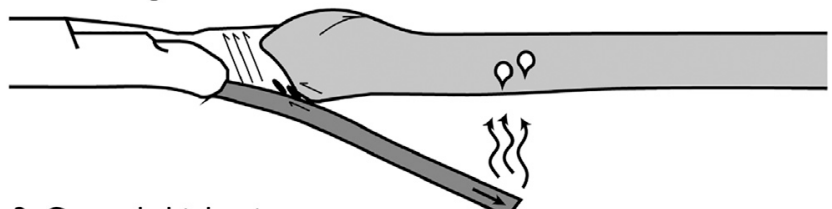

3. Crustal thickening

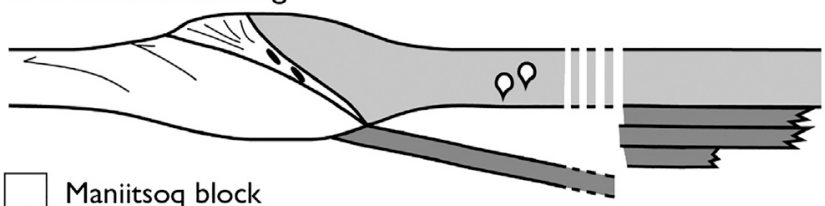

Maniitsoq block

North Atlantic Craton/

Fiskefjord Block

pP Qôrqut granite complex

Supracrustal rocks

II Ultramafic rocks

FIGURE 10| Plate-tectonic model for the Majorqaq belt with southward subduction at $2.55 \mathrm{Ga}$, contemporaneous with emplacement of the Qôrqut granite complex in Godthåbsfjord (Figure 1). Modified from Dyck et al. (2015).

\section{DISCUSSION}

This brief review of the geology of, and recent research in, the Greenlandic section of the NAC provides us with the opportunity to evaluate that geology in terms of the current, polemic debate about the controversial uniformitarian versus nonuniformitarian models.

\section{Contrasting Interpretations in the Northern Fiskefjord Block}

We begin with an examination of contrasting interpretations of the northern Fiskefjord block, where Yakymchuk et al. (2020) recently proposed a non-uniformitarian, stagnant lid model of $3.0 \mathrm{Ga}$ crustal accretion within the area of the Maniitsoq structure. Non-uniformitarian crustal accretion models for the Meso-to Neoarchaean NAC are rare, and the new model is interesting. Yakymchuk et al. (2020) examined static partial melting in mafic lithologies and argued that their observations are compatible with production of voluminous TTG partial melts at around 3.0 Ga from mafic lower crust in a static or extensional scenario with an unusually steep geothermal gradient and relatively thin crust. They argued that the effect of supposed crustal thinning was effective simultaneously over a large area and can therefore not only be explained by accretionary processes. They did not, however, supply observational support for crustal extension or test their model against the Maniitsoq structure. In the Maniitsoq structure, the biotite melt seams in cataclastic plagioclase and disequilibrium microstructures of three coexisting feldspars in granitic gneisses document a very large, but short-lived temperature excursion, to at least $1,300-1,400^{\circ} \mathrm{C}$ (Scherstén and Garde, 2013; Keulen et al., 2015), succeeded by long-term lower-crustal thermal perturbation under tectonically static conditions. Whereas the concept of large-scale mechanical mixing of cataclastic rocks in the lower crust is clearly beyond all normal endogenic crustal paradigms, it is familiar to scientists studying collisional planetary processes and impacts (e.g.Morgan et al., 2016). As argued by the latter authors and Garde et al. (2012b) a meteorite impact is the only way to achieve these relations. In regard to the stagnant lid model of Yakymchuk et al. (2020) this implies that at 3.0 Ga heat was supplied to the lower crust from above and not only from below, which makes the calculation of a normal crustal gradient redundant. On the other hand, their field observations of rock fragmentation (their Figure 2A), partial melting in the mafic lithologies, the ages of the partial melts, and the local P-T modelling are all fully compatible with a giant meteorite impact: Keulen et al. (2015) showed what happened to lower-crustal granitic gneisses in this scenario, whereas Yakymchuk et al. (2020) have demonstrated some high-temperature effects in equivalent mafic lithologies. In conclusion, a stagnant lid model for the northern Fiskefjord block may be speculatively possible, but it does not provide a satisfactory solution to the available salient information.

The proposition by Kirkland et al. (2018) of a new orogenic cycle in the northern Fiskefjord block relies heavily on a highly unusual and controversial interpretation of homogeneous felsic layers as sedimentary in origin, and on complex zircon age data with lead loss, must be viewed with caution. Citing Yakymchuk et al. (2020), "Evidence for radiogenic-Pb loss, in U-Pb age data and zircon morphologies, is very common in zircon from Mesoarchaean orthogneiss of the Akia Terrane (Friend and Nutman, 1994; Garde et al., 2012b; Kirkland et al., 2018; Gardiner et al., 2019).” Further discussion of the shortcomings of this proposition is not relevant for a general readership and is not pursued here.

\section{Uniformitarian Plate-Tectonic Processes in a Wider Perspective}

The evidence from West Greenland demonstrates that the geological components and their mutual relations are somewhat different from those in many parts of the world that have largely provided the database for most nonuniformitarian experimental-geochemical-isotopic models. We ask the question: are the geological features and relations in West Greenland, of whatever Archaean age, more consistent and compatible with the manifold variations of the modern plate tectonic paradigm, or are they so different that they require nonuniformitarian models such as vertical tectonics, gravity-driven sagduction, diapirism, delamination, drip tectonics, stagnant lid tectonics, heat pipes, or crustal overturn (e.g., Bédard et al., 2013; Moore and Webb, 2013; Thébaud and Rey 2013), as pointed out by Polat et al. (2015) and Windley et al. (2020). In other words, are the Archaean geological relations in West Greenland consistent with the idea that modern-style plate tectonics began at: 
A. 4.0 Ga or soon after (e.g., Maruyama et al., 1991; de Wit and Hart, 1993; Windley 1995; Nutman et al., 1996; Komiya et al., 1999; Polat et al., 2002; Polat and Hoffmann, 2003; Maruyama and Komiya, 2011; Arndt 2013; de Wit and Furnes, 2013; Kusky et al., 2013; Komiya et al., 2015; Nutman, 2015a; Nutman et al. 2015b; Polat, 2015; Windley et al., 2020).

B. At around 3.2-3.0 Ga (Cawood et al., 2006; Pease et al., 2008; Shirey and Richardson, 2011; van Kranendonk, 2011; Dhuime et al., 2012; Dhuime et al., 2015; Bauer et al., 2020).

C. From 3.2/3.0 Ga to 2.7/2.5 Ga (Condie and Kröner, 2008; Cawood et al., 2018; Nebel et al., 2018; O’Neill et al., 2018).

D. From 2.7 to 1.8 Ga (Bédard, 2006; Brown, 2010; Keller and Schoene, 2012).

E. Not at all in the Archaean (Hamilton, 1998; Harris and Bédard, 2014).

F. At 1.2-1.0 Ga (Stern, 2008; Stern, 2018).

First, we emphasise that for the last 50 years or so there has been a near-total consensus by a huge number of workers in all Earth Science disciplines, who studied the Archaean geology of West Greenland, that the geological relationships are without doubt compatible with equivalent accretionary or collisional processes in the Mesozoic-Cenozoic Earth. As pointed out by Friend and Nutman (2019), the evidence of partial melting of the upper mantle by a hydrous fluid flux, and the absence of komatiites in West Greenland strongly indicate a plate-tectonic regime rather than plume-driven vertical tectonics. A recent boron isotope study by Smit et al. (2019) is a possible exception to the general consensus; the authors suggested that the boron isotopic composition of TTGs seems to be incompatible with derivation primarily from subducted, hydrated oceanic crust. There are several ways in which non-uniformitarian models may impinge upon interpretation of the geology of West Greenland. In principle, there are two types of orogens: accretionary and collisional. Accretionary orogens (Cawood et al., 2009), like the Phanerozoic Japanese Islands (Isozaki et al., 1990; Isozaki et al., 2010) or the Altaids of Central Asia (Wilhem et al., 2012), form by the accretion of small fragments of mid-ocean ridges, ophiolites, ocean plate stratigraphy, seamounts, oceanic plateaus and island arcs. These are fragmental orogens because subduction erosion during offscraping accretion caused most ocean floor rocks to be subducted, and only a few to be accreted (Kimura and Ludden, 1995). Therefore, accretionary orogens do not contain or belong to a global network of plate boundaries (the putative requirements for plate tectonics of Cawood et al., 2018 and Brown et al., 2020), but rather only short boundaries (which arguably cannot even be called plate boundaries) that surround small relicts of island arcs, ophirags, and other rocks. Significantly, accretionary orogens were predominant in the Archaean, when the Earth's lithospheric plates were forming by oceanic tectonics, and that was before the development of large, stable and rigid continental plates in the Palaeoproterozoic, which evolved via the Wilson Cycle (Windley et al., 2020).

Collisional orogens, on the other hand, form by the collision of two continental blocks, like the Himalayas between India and Eurasia, during the final stage in the evolution of a Wilson Cycle (Windley 1995). Accordingly, collisional orogens typically contain long sutures along convergent plate boundaries, which have been maintained for considerable periods. The Himalayan example demonstrates that such a definable boundary can extend for thousands of kilometres from the Pyrenees to Malaysia with a global network of linked plate boundaries.

Returning to West Greenland, the Archaean rocks formed in two main periods, the Eo- and Mesoarchaean. In the Eoarchaean from ca. 3.9-3.6 Ga ago the Itsaq Gneiss Complex contains both the Isua belt and younger plutonic TTG gneisses (Nutman et al., 1996; Komiya et al., 1999; Nutman et al., 2004; Friend and Nutman 2005b; Friend and Nutman, 2013; Friend and Nutman, 2015a; Friend and Nutman, 2019), as well as a few other Eoarchaean fragments, the largest of which is the Aasivik terrane. Although disputed by Friend and Nutman (2019 and references therein) different parts of the Isua belt contain an upward succession from basal low-K tholeiitic basalts with or without pillows, thinly bedded cherts and magnetite-BIF, to uppermost mixed turbidites and conglomerates, which Komiya et al. $(1999,2004)$ pointed out is essentially identical to modern Ocean Plate Stratigraphy (Kusky et al., 2013), which is transported horizontally to a trench. Bolhar et al. (2004) reported that the REE, yttrium patterns, and diagnostic anomalies $\left(\mathrm{Ce} / \mathrm{Ce}^{\star}\right.$ and $\left.\mathrm{Pr} / \mathrm{Pr}^{\star}\right)$ of the magnetite-quartz banded iron formation (BIF), magnetitecarbonate BIF, and banded magnetite-rich quartz rocks are entirely comparable with the same diagnostic trace-element patterns of modern sedimentary equivalents and seawater proxies. These relations strongly suggest that these Eoarchaean rocks in Greenland formed in a horizontal tectonic regime in one or more subduction-accretion complexes (Friend and Nutman, 2019). Furthermore, from their detailed structural studies Hanmer and Greene (2002) reported that the Isua belt is underlain by a major $3.64 \mathrm{Ga}$ mylonitic thrust-nappe stack. The whole geologicalstructural regime demonstrates that the deformational behaviour, rheology, and overall strength of the Palaeoarchaean and modern continental crust were fundamentally similar.

The bulk of the Greenland craton consists largely of Mesoarchaean TTG gneisses, the protoliths of which were intruded into and intercalated with metavolcanic arc-type belts (such as Qussuk-Bjørneøen, Tartoq, Ivisaartoq, Ravns Storø and Nigerlikasik, described above) and layered anorthositic intrusions (such as the Fiskenæsset and Ivittuut complexes) that formed in island arcs. All these upper and lower crustal rocks were thrustimbricated by subhorizontal shortening, as evidenced by abundant early thrusts and associated recumbent isoclinal folds, followed by upright folding by crustal shortening. As shown by Grocott et al. (1999) and Grocott and McCaffrey (2017) this is also the case in the two Palaeoproterozoic orogens bounding the NAC in West Greenland, where large, dome-like compressional folds had previously been interpreted as crustal diapirs. All the wellpublished geological, structural, geochemical and isotopic data of these Mesoarchaean rocks in Greenland point to a subhorizontal tectonic regime. Confirmation of this tectonic setting comes from $2.7 \pm 0.3 \mathrm{Ga}$ eclogite xenoliths in a West Greenland kimberlite, which are coeval with the regional TTG magmatism (Tappe et al., 2011). Major and trace element systematics demonstrate that the eclogite garnets have elevated $\delta^{18} \mathrm{O}$ values and negative $\mathrm{Eu}$ anomalies that suggest their protoliths 
were derived from seafloor-altered oceanic crust and grew by melting of a basaltic slab in a subduction zone.

Now we return to the question of the relevance of the West Greenland rocks to the current non-uniformitarian models for Archaean crustal evolution, most of which are based on vertical, gravity-driven tectonics. It has been argued that the start or early operation of plate tectonics on Earth can "only be defined if the rocks can be shown to belong to a global system of plate boundaries" (Cawood et al., 2018; Brown et al., 2020). We fundamentally disagree with this conclusion, because all the papers and observations used to construct this model considered only the application of long-boundary collisional orogens and tectonics, and noticeably failed to consider the fact that the bulk of early to mid-Archaean orogens did not form by collisional tectonics because they are accretionary orogens, and accretionary orogens do not belong to "a globally linked system of plates," as described above and by Windley et al. (2020).

The North Atlantic craton as defined by Bridgwater et al. (1973 a, b) included not only the Archaean craton of Greenland, but also the Saglek block of Labrador in Canada. The Nulliak supracrustal belt at Saglek has been well described and comprehensively analysed by inter alia Komiya et al. (2015), who showed that it consists of an Eoarchaean accreted package of (in ascending primary stratigraphic order) ultramafic rocks, basalts, bedded white and green cherts, pelites, conglomerates and psammites; this is a typical ridge-ocean floor pelagic-trench assemblage that evolves on a moving oceanic plate. This Nulliak pile of volcanicsedimentary rocks contains imbricate thrust duplexes with roof, floor and link thrusts; this type of structure and stratigraphy can only be explained tectonically by the accretion of horizontaltravelled ocean floor rocks in a subduction trench setting. Accordingly, the Labrador segment of the NAC provides indubitable evidence of an Archaean horizontal tectonic regime, which is entirely consistent with that in West Greenland.

\section{CONCLUSIONS}

(1) The Eo-to Neoarchaean orogens in West Greenland formed by accretionary, autochthonous, plate tectonic subhorizontal, rather than vertical, processes.

(2) Other accretionary orogens that formed in the early Archaean (e.g. Nulliak, Barberton, Nuvvuagittuq, and Yilgarn) are not significantly different from those in the Neoarchaean belts of the Superior and Slave Cratons in Canada. There are some minor differences, but they are not greater than the differences between different Phanerozoic accretionary orogens

(3) The period of 3.2-3.0 Ga did not mark the onset of modern-style plate tectonics (e.g., van Kranendonk, 2011; Dhuime et al., 2015; Tang et al., 2016), nor the start of the Wilson Cycle (e.g., Shirey and Richardson, 2011), see Windley et al. (2020). The evidence that the Rb-Sr ratio and silica content of juvenile crust increased dramatically at 3.2-3.0 Ga (Dhuime et al., 2015) and that the crust before $3.0 \mathrm{Ga}$ had a highly mafic bulk composition, and a more felsic bulk composition after that mirrors exactly what takes place in the modern Earth, when juvenile oceanic crust and primitive oceanic island arcs change to a more $\mathrm{Si}$ - and $\mathrm{Rb}$-rich felsic crust in
Andean-type tonalitic magmatic arcs in active continental margins. The period $3.2-3.0 \mathrm{Ga}$ marks the time in all Archaean cratons of the progressive development of a rigid lithosphere; from a juvenile oceanic crustal regime to a more mature continental-influenced crust at a convergent plate boundary; the period 3.2-3.0 Ga does not mark the onset of plate tectonics, and certainly not the start of the Wilson Cycle, as so presciently and well reported by de Wit and Hart (1993) see also Windley et al. (2020). The major change at 3.2-3.0 Ga is well recorded in West Greenland when the more juvenile Eoarchaean oceanic crust in the Isua supracrustal belt changed to the TTGdominant protoliths of the widespread Mesoarchaean gneisses.

(4) Eighty per cent of the Archaean craton consists of $3.25-2.82 \mathrm{Ga}$ lower-crustal TTG gneisses, which have been inter-thrusted with upper crustal arc-derived volcanic rocks and anorthositic complexes.

(5) Neoarchaean thrusting and folding of previously accreted terranes took place in the Nuuk region and the Sermilik block at 2.85-2.65 Ga, and probably also in the Neria nappe in the Kvanefjord block (Windley and Garde, 2009), most likely as a result of collision tectonics (Dziggel et al., 2019; Friend and Nutman, 2019).

(6) With regard to the current controversy of whether plate tectonics started at c. $3.9 \mathrm{Ga}$ or 3.2-3.0 Ga, like Windley et al. (2020) we reiterate and emphasise the well-documented fact that the evolution of the Archaean craton of West Greenland took place in two main periods:

A. In the Eoarchaean Itsaq Gneiss Complex, which is extremely well documented by many publications over at least 20 years by Allen Nutman, Clark Friend, their colleagues and many others, which led to the conclusion that juvenile crust formation took place between 3,900 and 3,600 Ma in a proto-arc by episodic growth at a convergent, incipient plate boundary (Friend and Nutman, 2019).

B. At 3.25-2.82 Ga when the bulk of the Archaean craton formed when upper crustal island arc-generated volcanic rocks and anorthositic complexes were inter-thrusted with lower crustal TTG gneisses, the protoliths of which were generated in active continental magmatic margins.

Thus, the NAC contains abundant evidence of semicontinuous crustal growth by modern-style plate tectonic processes throughout the bulk of the Archaean. The geological relations in West Greenland and Labrador within the North Atlantic Craton were fortunately mapped and interpreted from more assured, basic principles in the field constrained by appropriate geochemical and isotopic age data, without recourse to theoretical and speculative laboratory-based models.

\section{AUTHOR CONTRIBUTIONS}

All four authors participated in writing the manuscript, with AG and BW being responsible for the major part. AG prepared and compiled the illustrations. All four authors contributed with their intimate knowledge of various parts of the North Atlantic craton based on previous and ongoing field and laboratory work. 


\section{FUNDING}

There was no specific funding for this work, whereas previous field and laboratory work was mainly supported by the Geological Survey of Denmark and Greenland, with additional contributions for field work from the Ministry of Mineral Resources of the Greenland Government.

\section{REFERENCES}

Andersen, L. S. and Friend, C. (1973). Structure of the Ravns Storø amphibolite belt in the Fiskenæsset region. Rapp. Grønlands geol. Unders. 51, 37-40.

Aoki, S., Kabashima, C., Kato, Y., Hirata, T., and Komiya, T. (2018). Influence of contamination on banded iron formations in the Isua supracrustal belt, West Greenland: reevaluation of the Eoarchean seawater compositions. Geosci. Front. 9, 1049-1072. doi:10.1016/j.gsf.2016.11.016

Appel, P. W. U., Fedo, C. M., Moorbath, S., and Myers, J. S. (1998). Recognizable primary volcanic and sedimentary features in a low-strain domain of the highly deformed, oldest known $(\approx 3.7-3.8 \mathrm{Gyr})$ greenstone belt, Isua, West Greenland. Terra Nova 10, 57-62. doi:10.1046/j.1365-3121.1998.00162.x

Appel, P. W. U. and Ghisler, M. (2014). Ruby- and sapphirine-bearing mineral occurrences in the Fiskenæsset, Nuuk and Maniitsoq regions, West Greenland. Danmark og Grønlands Geologiske Undersøgelse Rapport 2014/ $72,71 \mathrm{pp}$.

Appel, P. W. U. and Jensen, A. (1987). A new gem material from Greenland: iridescent orthoamphibole, Gems Gemol. 23, 36-42. doi:10.5741/gems.23.1.36

Appel, P. W. U. and Secher, K. (1984). On a gold mineralization in the Precambrian Tartoq group, SW Greenland, J. Geol. Soc. 141, 273-278. doi:10.1144/gsigs.141. 2.0273

Arai, T., Omori, S., Komiya, T., and Maruyama, S. (2015). Intermediate P/T-type regional metamorphism of the Isua Supracrustal Belt, southern West Greenland: the oldest Pacific-type orogenic belt?. Tectonophysics 662, 22-39. doi:10.1016/j.tecto.2015.05.020

Arndt, N. (2013). Formation and evolution of the continental crust. Geochem. (Tokyo. 1967) 2, 405-533. doi:10.7185/geochempersp.2.3

Arth, J. G. and Hanson, G. N. (1972). Quartz diorites derived by partial melting of eclogite or amphibolite at mantle depths. Contrib. Mineral. Petrol. 37, 161-174. doi:10.1007/bf00371074

Bauer, A. B., Reimink, J. R., Chacko, T., Foley, B. J., Shirey, S. B., and Pearson, D. G. (2020). Hafnium isotopes in zircons document the gradual onset of mobile-lid tectonics. Geochem. Persp. Let. 14, 1-6. doi:10.7185/geochemlet.2015

Bédard, J. H. (2006). A catalytic delamination-driven model for coupled genesis of Archaean crust and sub-continental lithospheric mantle. Geochem. Cosmochim. Acta 70, 1188-1214. doi:10.1016/j.gca.2005.11.008

Bédard, J. H., Harris, L. B., and Thurston, P. C. (2013). The hunting of the snArc. Precambrian Res. 229, 20-48. doi:10.1016/j.precamres.2012.04.001

Bernstein, S., Kelemen, P. B., and Brooks, C. K. (1998). Depleted spinel harzburgite xenoliths in Tertiary dykes from East Greenland: restites from high degree melting. Earth Planet Sci. Lett. 154, 221-235. doi:10.1016/s0012-821x(97) 00175-1

Bernstein, S., Kelemen, P. B., and Hanghøj, K. (2007). Consistent olivine Mg\# in cratonic mantle reflects Archean mantle melting to the exhaustion of orthopyroxene. Geol. 35, 459-462. doi:10.1130/g23336a.1

Berthelsen, A. and Henriksen, N. (1975). Geological Map of Greenland, 1:100 000, ivigtut 61 V.1 syd (with map description). Copenhagen, Denmark: Geological Survey of Greenland.

Berthelsen, A. (1960). Structural studies in the pre-Cambrian of western Greenland. II. Geology of Tovqussap nunâ. Bull. Grønlands geol. Unders. 25, 223 pp. (also Meddelelser om Grønland 135(6))

Berthelsen, A. (1962). Structural studies on the Pre-Cambrian of western Greenland. III. Southern Sukkertoppen district. Bull. Grønlands geol. Unders. 31, 47 pp. (also Meddelelser om Grønland 123(2)).

Bolhar, R., Kamber, B. S., Moorbath, S., Fedo, C. M., and Whitehouse, M. J. (2004). Characterisation of early Archaean chemical sediments by trace element signatures. Earth Planet Sci. Lett. 222, 43-60. doi:10.1016/j.epsl.2004.02.016

\section{ACKNOWLEDGMENTS}

We thank the editors for their invitation to contribute to the present volume, Martin B. Klausen for his contribution to the Nigerlikasik belt and compilation of Figure 6, Annika Dziggel for comments on a previous version of this manuscript, and Allen Nutman, reviewer, and guest editor Martin Guitreau for constructive and helpful comments.

Bridgwater, D., Escher, A., Jackson, G. D., Taylor, F. C., and Windley, B. F. (1973a). "Development of the Precambrian shield in West Greenland, Labrador, and Baffin Island," in American Association of Petroleum Geologists, Arctic Geology, Tulsa, OK, American Association of Petroleum Geologists, Memoir, Vol. 19, 99-116.

Bridgwater, D., Keto, L., McGregor, V. R., and Myers, J. S. (1976). “Archaean gneiss complex of Greenland," in Geology of Greenland. Editors A. Escher and W. S. Watt (Copenhagen, Denmark: Geological Survey of Greenland), 18-75.

Bridgwater, D., McGregor, V. R., and Myers, J. S. (1974). A horizontal tectonic regime in the Archaean of Greenland and its implications for early crustal thickening. Precambrian Res. 1, 179-197. doi:10.1016/0301-9268(74)90009-6

Bridgwater, D., Watson, J., and Windley, B. F. (1973b). The Archaean craton of the North Atlantic region. Phil. Trans. Roy. Soc. Lond. A273, 493-512. doi:10.1098/ rsta.1973.0014

Brown, M. (2010). Duality of thermal regimes is the distinctive characteristic of plate tectonics since the Neoarchean. Geology 34, 961-964. doi:10.1130/ g22853a.1

Brown, M., Johnson, T., and Gardiner, N. J. (2020). Plate tectonics and the Archean Earth. Annu. Rev. Earth Planet Sci. 48, 12.1-30. doi:10.1146/annurev-earth081619-052705

Cawood, P. A., Hawkesworth, C. J., Pisarevsky, S. A., Dhuime, B., Capitanio, F. A., and Nebel, O. (2018). Geological archive of the onset of plate tectonics. Phil. Trans. R. Soc. A. 376, 20170405. doi:10.1098/rsta.2017.0405

Cawood, P. A., Kröner, A., Collins, W. J., Kusky, T. M., Mooney, W. D., and Windley, B. F. (2009). Accretionary orogens through Earth history, Geol. Soc., Lond., Special Publications 318. 1-36. doi:10.1144/sp318.1

Cawood, P. A., Kröner, A., and Pisarevsky, S. (2006). Precambrian plate tectonics: criteria and evidence. GSA Today (Geol. Soc. Am.) 16, 4-11. doi:10.1130/ gsat01607.1

Chadwick, B. (1990). The stratigraphy of a sheet of supracrustal rocks within highgrade orthogneisses and its bearing on late Archaean structure in southern West Greenland, J. Geol. Soc. 147, 639-652. doi:10.1144/gsjgs.147.4.0639

Condie, K. C. and Kröner, A. (2008). When did plate tectonics begin? Evidence from the geologic record. Geol. Soc. Am., Special Paper 440, 281-294. doi:10. $1130 / 2008.2440(14)$

Crowley, J. L. (2002). Testing the model of late Archean terrane accretion in southern West Greenland: a comparison of the timing of geological events across the Qarliit nunaat fault, Buksefjorden region. Precambrian Res. 116, 57-79. doi:10.1016/s0301-9268(02)00002-5

Dauphas, N., van Zuilen, M., Wadhwa, M., Davis, A. M., Marty, B., and Janney, P. E. (2004). Clues from Fe isotope variations on the origin of early Archean BIFs from Greenland. Science 306, 2077-2080. doi:10.1126/science.1104639

de Wit, M. and Furnes, H. (2013). Earth's oldest preserved unconformity - prospect of a beginning in the tectono-sedimentary continental cycle? Gondwana Res. 23, 429-435. doi:10.1016/j.gr.2012.03.002

de Wit, M. J. and Hart, R. A. (1993). Earth's earliest continental lithosphere, hydrothermal flux and crustal recycling. Lithos 30, 309-335. doi:10.1016/00244937(93)90043-c

Dhuime, B., Hawkesworth, C. J., Cawood, P. A., and Storey, C. D. (2012). A change in the geodynamics of continental growth 3 billion years ago. Science 335, 1334-1336. doi:10.1126/science. 1216066

Dhuime, B., Wuestefeld, A., and Hawkesworth, C. J. (2015). Emergence of modern continental crust about 3 billion years ago. Nat. Geosci. 8, 552-555. doi:10.1038/ ngeo2466

Dilek, Y. and Flower, M. F. J. (2003). "Arc-trench rollback and forearc accretion: 2. Model template for Albania, Cyprus, and Oman," Ophiolites In Earth History. Editors Y. Dilek and P. T. Robinson (London: Geological Society of London, Special Publications), 218, 43-68. 
Dyck, B., Reno, B. L., and Kokfelt, T. F. (2015). The Majorqaq belt: a record of neoarchaean orogenesis during final assembly of the North Atlantic Craton, southern west Greenland. Lithos 220-223, 253-271. doi:10.1016/j.lithos.2015.01.024

Dziggel, A., Diener, J. F. A., Kokfelt, T. F., Kolb, J., and Scherstén, A. (2019). Thermal structure and evolution of an Archean large hot orogen: insights from the Tasiusarsuaq terrane, SW Greenland. Precambrian Res. 335, 105499. doi:10. 1016/j.precamres.2019.105499

Dziggel, A., Diener, J. F. A., Kolb, J., and Kokfelt, T. F. (2014). Metamorphic record of accretionary processes during the Neoarchaean: the Nuuk region, southern West Greenland. Precambrian Res. 242, 22-38. doi:10.1016/j.precamres.2013.12.010

Dziggel, A., Diener, J. F. A., Stoltz, N. B., and Kolb, J. (2012). Role of H2O in the formation of garnet coronas during near-isobaric cooling of mafic granulites: the Tasiusarsuaq terrane, southern West Greenland. J. Metamorph. Geol. 30, 957-972. doi:10.1111/j.1525-1314.2012.01006.x

Dziggel, A., Kokfelt, T. F., Kolb, J., Kisters, A. F. M., and Reifenröther, R. (2017). Tectonic switches and the exhumation of deep-crustal granulites during Neoarchean terrane accretion in the area around Grædefjord, SW Greenland. Precambrian Res. 300, 223-245. doi:10.1016/j.precamres.2017.07.027

Escher, J. C. and Pidgeon, R. T. (1976). Field mapping of nunatak 1390 m, east of Alángordlia, southern west Greenland. Rapp. Grønlands geol. Unders. 80, 84-87.

Evans, D. M. and King, A. R. (1993). Sediment and shear-hosted gold mineralization of the Tartoq Group supracrustals, southwest Greenland. Precambrian Res. 62, 61-82. doi:10.1016/0301-9268(93)90094-i

Fedo, C. M. and Whitehouse, M. J. (2002). Metasomatic origin of quartz-pyroxene rock, Akilia, Greenland, and implications for earth's earliest life. Science 296, 1448-1452. doi:10.1126/science.1070336

Frei, R. and Polat, A. (2007). Source heterogeneity for the major components of 3.7 Ga banded iron formations (Isua greenstone belt, western Greenland): tracing the nature of interacting water masses in BIF formation. Earth Planet Sci. Lett. 253, 266-281. doi:10.1016/j.epsl.2006.10.033

French, B. M. and Koeberl, C. (2010). The convincing identification of terrestrial meteorite impact structures: what works, what doesn't, and why. Earth Sci. Rev. 98, 123-170. doi:10.1016/j.earscirev.2009.10.009

Friend, C. R. L., Nutman, A. P., Baadsgaard, H., and Duke, M. J. M. (2009). The whole rock Sm-Nd 'age' for the $2825 \mathrm{Ma}$ Ikkattoq gneisses (Greenland) is 800 Ma too young: insights into Archaean TTG petrogenesis. Chem. Geol. 261, 62-76. doi:10.1016/j.chemgeo.2008.09.019

Friend, C. R. L., Nutman, A. P., Bennett, V. C., and Norman, M. D. (2008). Seawater-like trace element signatures (REE $+\mathrm{Y})$ of Eoarchaean chemical sedimentary rocks from southern West Greenland, and their corruption during high-grade metamorphism. Contrib. Mineral. Petrol. 155, 229-246. doi:10. 1007/s00410-007-0239-z

Friend, C. R. L. and Nutman, A. P. (2005b). Complex 3670-3500 Ma orogenic episodes superimposed on juvenile crust accreted between 3850 and $3690 \mathrm{Ma}$, Itsaq gneiss complex, southern West Greenland. J. Geol. 113, 375-397. doi:10. $1086 / 430239$

Friend, C. R. L., Nutman, A. P., and McGregor, V. R. (1988). Late Archaean terrane accretion in the Godthåb region, southern West Greenland. Nature 335, 535-538. doi:10.1038/335535a0

Friend, C. R. L., Nutman, A. P., and McGregor, V. R. (1987). Late-Archaean tectonics in the Færingehavn-Tre Brødre area, south of Buksefjorden, southern West Greenland, J. Geol. Soc. 144, 369-376. doi:10.1144/gsjgs.144.3.0369

Friend, C. R. L. and Nutman, A. P. (2005a). New pieces to the Archaean terrane jigsaw puzzle in the Nuuk region, southern West Greenland: steps in transforming a simple insight into a complex regional tectonothermal model, J. Geol. Soc. 162, 147-162. doi:10.1144/0016-764903-161

Friend, C. R. L. and Nutman, A. P. (2019). Tectono-stratigraphic terranes in Archaean gneiss complexes as evidence for plate tectonics: the Nuuk region, southern West Greenland. Gondwana Res. 72, 213-237. doi:10.1016/j.gr.2019. 03.004

Friend, C. R. L. and Nutman, A. P. (1994). Two Archaean granulite-facies metamorphic events in the Nuuk-Maniitsoq region, southern West Greenland: correlation with the Saglek block, Labrador, J. Geol. Soc. 151, 421-424. doi:10.1144/gsigs.151.3.0421

Friend, C. R. L. and Nutman, A. P. (2001). U-Pb zircon study of tectonically bounded blocks of 2940-2840 Ma crust with different metamorphic histories, Paamiut region, South-West Greenland: implications for the tectonic assembly of the North Atlantic craton. Precambrian Res. 105, 143-164. doi:10.1016/ s0301-9268(00)00109-1

Garde, A. A. (1997). Accretion and evolution of an Archaean high-grade grey gneiss-amphibolite complex: the Fiskefjord area, southern West Greenland. Bull. Grønlands geol. Unders. 177, 115 pp.

Garde, A. A. (2007). A mid-Archaean island arc complex in the eastern Akia terrane, Godthåbsfjord, southern West Greenland. J. Geol. Soc. 164, 565-579.

Garde, A. A., Dyck, B., Esbensen, K. H., Johansson, L., and Möller, C. (2014). The Finnefjeld domain, Maniitsoq structure, West Greenland: differential rheological features and mechanical homogenisation in response to impacting? Precambrian Res. 255, 791-808. doi:10.1016/j.precamres.2014.06.022

Garde, A. A., Friend, C. R. L., Nutman, A. P., and Marker, M. (2000). Rapid maturation and stabilisation of middle Archaean continental crust: the Akia terrane, southern West Greenland. Bull. Geol. Soc. Den. 47, 1-27.

Garde, A. A., Johansson, L., and Lindgren, P. (2019). "Zircon microstructures from the Maniitsoq impact structure, West Greenland." in Proceedings of the 50th Lunar and Planetary Science Conference. Texas, United States. March 2019. Abstract \#1379.

Garde, A. A. and Klausen, M. B. (2016). A centennial reappraisal of the Vredefort pseudotachylytes: shaken, not stirred by meteorite impact, J. Geol. Soc. 173, 954-965. doi:10.1144/jgs2015-147

Garde, A. A., McDonald, I., Dyck, B., and Keulen, N. (2013a). Reply on "Searching for giant, ancient impact structures on Earth: the Mesoarchaean Maniitsoq structure, West Greenland" by Garde et al. [Earth and Planetary Science Letters 337-338:197-210]. Earth and planetary science letters, 369-370, 336-343.

Garde, A. A., McDonald, I., Dyck, B., and Keulen, N. (2012b). Searching for giant, ancient impact structures on Earth: the Mesoarchaean Maniitsoq structure, West Greenland. Earth Planet Sci. Lett. 337-338, 197-210. doi:10.1016/j.epsl. 2012.04.026

Garde, A. A., Pattison, J., Kokfelt, T. F., McDonald, I., and Secher, K. (2013b). The norite belt in the Mesoarchaean Maniitsoq structure, southern West Greenland: conduit-type $\mathrm{Ni}-\mathrm{Cu}$ mineralisation in impact-triggered, mantle-derived intrusions? Geol. Surv. Den. Greenl. Bull. 28, 45-48.

Garde, A. A. (1991). Post-kinematic diorite intrusions in Archaean basement rocks around outer Fiskefjord, southern West Greenland. Bull. Geol. Soc. Den. 39, $167-177$

Garde, A. A., Whitehouse, M., and Christensen, R. (2012a). Mesoarchean epithermal gold mineralization preserved at upper amphibolite-facies grade, Qussuk, southern West Greenland. Econ. Geol. 107, 881-908. doi:10.2113/ econgeo.107.5.881

Gardiner, N. J., Kirkland, C. J., Hollis, J., Szilas, K., Steenfelt, A., Yakymchuk, C., et al. (2019). Building mesoarchaean crust upon Eoarchaean roots: the Akia terrane, West Greenland. Contrib. Mineral. Petrol. 174, 20. doi:10.1007/s00410019-1554-x

Gardiner, N. J., Kirkland, C. L., Hollis, J. A., Cawood, P. A., Nebel, O., Szilas, K., et al. (2020). North Atlantic Craton architecture revealed by kimberlite-hosted crustal zircons. Earth Planet Sci. Lett. 534, 116091. doi:10.1016/j.epsl.2020.116091

Glikson, A. Y. (2013). The Asteroid Impact Connection of Planetary Evolution with Special Reference to Large Precambrian and Australian Impacts. Dordrecht: Springer, $149 \mathrm{pp}$.

Grocott, J., Garde, A. A., Chadwick, B., Cruden, A. R., and Swager, C. (1999). Emplacement of rapakivi granite and syenite by floor depression and roof uplift in the Palaeoproterozoic Ketilidian orogen, South Greenland. J. Geol. Soc. 156, 15-24. doi:10.1144/gsigs.156.1.0015

Grocott, J. and McCaffrey, K. J. W. 2017). Basin evolution and destruction in an Early Proterozoic continental margin: the Rinkian fold-thrust belt of central West Greenland. J. Geol. Soc. 174, 453-467. doi:10.1144/jgs2016-109

Guitreau, M., Boyet, M., Paquette, J.-L., Gannoun, A., Konc, Z., Benbakkar, M., et al. (2019). Hadean protocrust reworking at the origin of the Archean Napier complex (Antarctica). Geochem. Persp. Let. 12, 7-11. doi:10.7185/geochemlet. 1927

Guotana, J., Morishita, T., Yamaguchi, R., Nishio, I., Tamura, A., Tani, K., et al. (2018). Contrasting textural and chemical signatures of chromitites in the Mesoarchaean Ulamertoq peridotite body, southern West Greenland. Geosciences 8, 18. doi:10.3390/geosciences8090328

Hamilton, W. B. (1998). Archean magmatism and deformation were not products of plate tectonics. Precambrian Res. 91, 143-179. doi:10.1016/s0301-9268(98) $00042-4$ 
Hanmer, S. and Greene, D. C. (2002). A modern structural regime in the Paleoarchean $(\sim 3.64 \mathrm{Ga})$; Isua greenstone belt, southern west Greenland. Tectonophysics 346, 201-222. doi:10.1016/s0040-1951(02)00029-x

Harris, L. B. and Bédard, J. H. (2014). "Crustal evolution and deformation in a nonPlate-tectonic archaean earth: comparison with venus," in Evolution of Archean Crust and Early Life. Editors Y. Dilek and H. Furnes (Dordrecht: Springer), 215-291.

Herd, R. K., Windley, B. F., and Ghisler, M. (1969). The mode of occurrence and petrogenesis of the sapphirine-bearing and associated rocks of West Greenland. Rapp. Grønlands geol. Unders. 24, $44 \mathrm{pp}$.

Herzberg, C., Condie, K., and Korenaga, J. (2010). Thermal history of the earth and its petrological expression. Earth Planet Sci. Lett. 292, 79-88. doi:10.1016/j.epsl. 2010.01.022

Hiess, J., Bennett, V. C., Nutman, A. P., and Williams, I. S. (2009). In situ U-Pb, O and $\mathrm{Hf}$ isotopic compositions of zircon and olivine from Eoarchaean rocks, West Greenland: new insights to making old crust. Geochem. Cosmochim. Acta 73, 4489-4516. doi:10.1016/j.gca.2009.04.019

Higgins, A. K. and Bondesen, E. (1966). Supracrustals of preketilidian age (Tartoq group), and their relationships with Ketilidian supracrustals in the Ivigtut area, S.W. Greenland. Rapp. Grønlands geol. Unders. 8, 11 pp.

Higgins, A. K. (1968). The Tartoq group on Nuna qaqertoq and in the Iterdlak area, S.W. Greenland. Rapp. Grønlands geol. Unders. 17, 19 pp.

Hoffmann, J. E., Münker, C., Næraa, T., Rosing, M. T., Herwartz, D., GarbeSchönberg, D., et al. (2011). Mechanisms of Archean crust formation inferred from high-precision HFSE systematics in TTGs. Geochem. Cosmochim. Acta 75, 4157-4178. doi:10.1016/j.gca.2011.04.027

Hoffmann, J. E., Svahnberg, H., Piazolo, S., Scherstén, A., and Münker, C. (2012). The geodynamic evolution of Mesoarchean anorthosite complexes inferred from the Naajat Kuuat Complex, southern West Greenland. Precambrian Res. 196-197, 149-170. doi:10.1016/j.precamres.2011.12.002

Huang, H., Polat, A., Fryer, B. J., Appel, P. W. U., and Windley, B. F. (2012). Geochemistry of the mesoarchean Fiskenæsset complex at Majorqap qâva, SW Greenland: evidence for two different magma compositions. Chem. Geol. 314-317, 66-82. doi:10.1016/j.chemgeo.2012.04.020

Isozaki, Y., Aoki, K., Nakama, T., and Yanai, S. (2010). New insight into a subduction-related orogen: a reappraisal of the geotectonic framework and evolution of the Japanese Islands. Gondwana Res. 18, 82-105. doi:10.1016/j.gr. 2010.02 .015

Isozaki, Y., Maruyama, S., and Furuoka, F. (1990). Accreted oceanic materials in Japan. Tectonophysics 181, 179-205. doi:10.1016/0040-1951(90)90016-2

Kalsbeek, F. and Hansen, M. (1989). Statistical analysis of Rb-Sr isotope data by the "bootstrap" method. Chem. Geol. Isot. Geosci. 73, 289-297. doi:10.1016/01689622(89)90022-5

Kalsbeek, F. and Myers, J. S. (1973). The geology of the Fiskenæsset region. Rapp. Grønlands geol. Unders. 51, 5-18.

Kamber, B. S., Moorbath, S., and Whitehouse, M. J. (2001). The oldest rocks on Earth: time constraints and geological controversies, Geol. Soc., Lond., Special Publications 190, 177-203. doi:10.1144/gsl.sp.2001.190.01.13

Kawai, T., Windley, B. F., Terabayashi, M., Yamamoto, H., Maruyama, S., Omori, S., et al. 2007). Geotectonic framework of the Blueschist Unit on AngleseyLleyn, UK, and its role in the development of a Neoproterozoic accretionary orogen. Precambrian Res. 153, 11-28. doi:10.1016/j.precamres.2006.11.002

Keller, C. B. and Schoene, B. (2012). Statistical geochemistry reveals disruption in secular lithospheric evolution about $2.5 \mathrm{Gyr}$ ago. Nature 485, 490-493. doi:10. 1038/nature1 1024

Keulen, N., Garde, A. A., and Jørgart, T. (2015). Shock melting of K-feldspar and interlacing with cataclastically deformed plagioclase in granitic rocks at Toqqusap Nunaa, southern West Greenland: implications for the genesis of the Maniitsoq structure. Tectonophysics 662, 328-344. doi:10.1016/j.tecto.2015. 07.028

Keulen, N., Næraa, T., Kokfelt, T. F., Schumacher, J. C., and Scherstén, A. (2010). Zircon record of the igneous and metamorphic history of the Fiskenæsset anorthosite complex in southern West Greenland. Geol. Surv. Den. Greenl. Bull. 20, 67-70.

Keulen, N., Schumacher, J. C., Næraa, T., Kokfelt, T. F., Scherstén, A., Szilas, K., et al. 2014). Meso- and Neoarchaean geological history of the Bjørnesund and Ravns Storø supracrustal belts, southern west Greenland: settings for gold enrichment and corundum formation. Precambrian Res. 254, 36-58. doi:10. 1016/j.precamres.2014.07.023

Keulen, N., Schumacher, J., and Kokfelt, T. F. (2011). Notes on the structural profiles related to the 1:100 000 digital geological map of southern West and South-West Greenland, 61 $30-64^{\circ}$ N. Danmark og Grønlands Geologiske Undersøgelse Rapport 2011/13, 70 pp.

Keulen, N., Thomsen, T. B., Schumacher, J. C., Poulsen, M. D., Kalvig, P., Vennemann, T., et al. (2020). Formation, origin and geographic typing of corundum (ruby and pink sapphire) from the Fiskenæsset complex, Greenland. Lithos 366-367, 105536. doi:10.1016/j.lithos.2020.105536

Kimura, G. and Ludden, J. (1995). Peeling oceanic crust in subduction zones. Geology 23, 217-220. doi:10.1130/0091-7613(1995)023<0217:pocisz>2.3.co;2

Kirkland, C. L., Yakymchuk, C., Hollis, J., Heide-Jørgensen, H., and Danišík, M. (2018). Mesoarchean exhumation of the Akia terrane and a common Neoarchean tectonothermal history for West Greenland. Precambrian Res. 314, 129-144. doi:10.1016/j.precamres.2018.06.004

Kisters, A. F. M., van Hinsberg, V. J., and Szilas, K. (2012). Geology of an Archaean accretionary complex - the structural record of burial and return flow in the Tartoq Group of South West Greenland. Precambrian Res. 220-221, 107-122. doi:10.1016/j.precamres.2012.07.008

Klausen, M. B., Szilas, K., Kokfelt, T. F., Keulen, N., Schumacher, J. C., and Berger, A. (2017). Tholeiitic to calc-alkaline metavolcanic transition in the archean Nigerlikasik supracrustal belt, SW Greenland. Precambrian Res. 302, 50-73. doi:10.1016/j.precamres.2017.09.014

Kokfelt, T. F., Keulen, N., Næraa, T., Scherstén, A., and Heijboer, T. (2011). New zircon $\mathrm{U} / \mathrm{Pb}$ age data from the Archaean craton. South-West and southern West Greenland $\left(61^{\circ} 30^{\prime} \mathrm{N}-64^{\circ} 00^{\prime} \mathrm{N}\right)$. EGU2011-14038.

Kolb, J., Dziggel, A., and Schlatter, D. M. (2013). Gold occurrences of the Archean North Atlantic craton, southwestern Greenland: a comprehensive genetic model. Ore Geol. Rev. 54, 29-58. doi:10.1016/j.oregeorev.2013.01.019

Kolb, J., Kokfelt, T. F., and Dziggel, A. (2012). Geodynamic setting and deformation history of an Archaean terrane at mid-crustal level: the Tasiusarsuaq terrane of southern West Greenland. Precambrian Res. 212-213, 34-56. doi:10.1016/j.precamres.2012.04.010

Komatsu, M., Osanai, Y., Toyoshima, T., and Miyashita, S. (1989). "Evolution of the Hidaka metamorphic belt, northern Japan," in Evolution of Metamorphic Belts. Editors J. S. Daly, R. A. Cliff, and B. W. D. Yardley (London: Geological Society of London, Special Publications), 43, 487-493.

Komiya, T., Maruyama, S., Hirata, T., Yurimoto, H., and Nohda, S. (2004). Geochemistry of the oldest MORB and OIB in the Isua Supracrustal Belt, southern West Greenland: implications for the composition and temperature of early Archean upper mantle. Isl. Arc 13, 47-72. doi:10.1111/j.1440-1738.2003.00416.x

Komiya, T., Maruyama, S., Masuda, T., Nohda, S., Hayashi, M., and Okamoto, K. (1999). plate tectonics at 3.8-3.7 Ga: field evidence from the Isua accretionary complex, southern west Greenland. J. Geol. 107, 515-554. doi:10.1086/314371

Komiya, T. (2004). Material circulation model including chemical differentiation within the mantle and secular variation of temperature and composition of the mantle. Phys. Earth Planet. In. 146, 333-367. doi:10.1016/j.pepi.2003.03.001

Komiya, T. (2007). "Material circulation through time: chemical differentiation within the mantle and secular variation of temperature and composition of the mantle," in Superplumes: beyond plate tectonics. Editors D. A. Yuen, S. Maruyama, S. I. Karato, and B. F. Windley (Dordrecht: Springer), 187-234.

Komiya, T., Yamamoto, S., Aoki, S., Sawaki, Y., Ishikawa, A., Tashiro, T., et al. (2015). Geology of the Eoarchean, $>3.95 \mathrm{Ga}$, Nulliak supracrustal rocks in the Saglek Block, northern Labrador, Canada: the oldest geological evidence for plate tectonics. Tectonophysics 662, 40-66. doi:10.1016/j.tecto.2015.05.003

Kusky, T. M., Windley, B. F., Safonova, I., Wakita, K., Wakabayashi, J., Polat, A., et al. (2013). Recognition of ocean plate stratigraphy in accretionary orogens through Earth history: a record of 3.8 billion years of sea floor spreading, subduction, and accretion. Gondwana Res. 24, 501-547. doi:10.1016/j.gr.2013. 01.004

Leggett, J. K., McKerrow, W. S., and Eales, M. H. (1979). The southern uplands of Scotland: a lower palaeozoic accretionary prism, J. Geol. Soc. 136, 755-770. doi:10.1144/gsjgs.136.6.0755

Lepland, A., van Zuilen, M. A., Arrhenius, G., Whitehouse, M. J., and Fedo, C. M. (2005). Questioning the evidence for Earth's earliest life-Akilia revisited. Geology 33, 77-79. doi:10.1130/g20890.1 
Manning, C. E., Mojzsis, S. J., and Harrison, T. M. (2006). Geology, age and origin of supracrustal rocks at Akilia, West Greenland. Am. J. Sci. 306, 303-366. doi:10.2475/05.2006.02

Maruyama, S. and Komiya, T. (2011). The oldest pillow lavas, 3.8-3.7Ga from the Isua supracrustal belt, SW Greenland: plate Tectonics had already begun by 3.8Ga. J. Geogr. 120 (5), 869-876. doi:10.5026/jgeography.120.869

Maruyama, S., Masuda, T., and Appel, P. W. U. (1991). The oldest accretionary complex on the Earth, Isua, Greenland with program. Geol. Soc. Am. 23, A429-A430.

McGregor, V. R. and Friend, C. R. L. (1997). Field recognition of rocks totally retrogressed from granulite facies: an example from Archaean rocks in the Paamiut region, South-West Greenland. Precambrian Res. 86, 59-70. doi:10. 1016/s0301-9268(97)00041-7

McGregor, V. R. and Friend, C. R. L. (1992). Late archean prograde amphibolite- to granulite-facies relations in the Fiskenæsset region, southern West Greenland. J. Geol. 100, 207-219. doi:10.1086/629583

McGregor, V. R., Friend, C. R. L., and Nutman, A. P. (1991). The late Archaean mobile belt through Godthåbsfjord, southern West Greenland: a continentcontinent collision zone? Geol. Soc. Den. Bull. 39, 179-197.

McGregor, V. R. and Mason, B. (1977). Petrogenesis and geochemistry of metabasaltic and metasedimentary enclaves in the Amitsoq gneisses. Am. Mineral. 62, 887-904.

McGregor, V. R. (1973). The early Precambrian gneisses of the Godthåb district, West Greenland. Phil. Trans. Roy. Soc. Lond. A273, 343-358. doi:10.1098/rsta. 1973.0005

McKeegan, K. D., Kudryavtsev, A. B., and Schopf, J. W. (2007). Raman and ion microscopic imagery of graphitic inclusions in apatite from older than $3830 \mathrm{Ma}$ Akilia supracrustal rocks, West Greenland. Geol. 35, 591-594. doi:10.1130/ g23465a.1

Mojzsis, S. L., Arrhenius, G., McKeegan, K. D., Harrison, T. M., and Friend, C. R. L. (1996). Evidence for life on Earth before 3800 million years ago. Nature 270, 43-45.

Moorbath, S., O’Nions, R. K., and Pankhurst, R. J. (1973). Early Archaean age for the Isua iron formation, west Greenland. Nature 245, 138-139. doi:10.1038/ $245138 \mathrm{a} 0$

Moore, W. B. and Webb, A. A. G. (2013). Heat-pipe earth. Nature 501, 501-505. doi:10.1038/nature12473

Morgan, J. V., Gulick, S. P., Bralower, T., Chenot, E., Christeson, G., Claeys, P., et al. (2016). The formation of peak rings in large impact craters. Science 354, 878-882. doi:10.1126/science.aah6561

Moyen, J.-F. and Martin, H. (2012). Forty years of TTG research. Lithos 148, 312-336. doi:10.1016/j.lithos.2012.06.010

Myers, J. S. (1985). Stratigraphy and structure of the Fiskenæsset complex, southern west Greenland. Bull. Grønlands geol. Unders. 150, 72 pp.

Myers, J. S. and Crowley, J. L. (2000). Vestiges of life in the oldest Greenland rocks? A review of early Archean geology in the Godthåbsfjord region, and reappraisal of field evidence for $>3850$ Ma life on Akilia. Precambrian Res. 103, 101-124. doi:10.1016/s0301-9268(00)00089-9

Myers, J. S. (1976). Granitoid sheets, thrusting, and Archean crustal thickening in West Greenland. Geology 4, 265-268. doi:10.1130/0091-7613(1976)4<265: gstaac > 2.0.co;2

Næraa, T., Kemp, A. I. S., Scherstén, A., Rehnström, E. F., Rosing, M. T., and Whitehouse, M. J. (2014). A lower crustal mafic source for the ca. $2550 \mathrm{Ma}$ Qôrqut Granite Complex in southern West Greenland. Lithos 192, 291-304. doi:10.1016/j.lithos.2014.02.013

Næraa, T. and Scherstén, A. (2008). New zircon ages from the Tasiusarsuaq terrane, southern West Greenland. Geol. Surv. Den. Greenl. Bull. 15, 73-76. doi:10.34194/geusb.v15.5048

Næraa, T., Scherstén, A., Rosing, M. T., Kemp, A. I. S., Hoffmann, J. E., Kokfelt, T., et al. (2012). Hafnium isotope evidence for a transition in the dynamics of continental growth 3.2 Gyr ago. Nature 485, 67-631. doi:10.1038/nature11140

Nebel, O., Capitanio, F. A., Moyen, J.-F., Weinberg, R. F., Clos, F., Nebel-Jacobsen, Y. J., et al. (2018). When crust comes of age: on the chemical evolution of Archaean, felsic continental crust by crustal drip tectonics. Phil. Trans. R. Soc. A. 376, 20180103. doi:10.1098/rsta.2018.0103

Nutman, A. and Friend, C. (2007). Adjacent terranes with ca. 2715 and 2650Ma high-pressure metamorphic assemblages in the Nuuk region of the North Atlantic Craton, southern West Greenland: complexities of Neoarchaean collisional orogeny. Precambrian Res. 155, 159-203. doi:10.1016/j.precamres. 2006.12.009

Nutman, A. P., Bennett, V. C., Friend, C. R. L., and Keewook, Y. (2020). Eoarchaean contrasting ultra-high-pressure to low-pressure metamorphisms $\left(<250\right.$ to $\left.>1000^{\circ} \mathrm{C} / \mathrm{GPa}\right)$ explained by tectonic plate convergence in deep time. Precambrian Res. 344, 105770. doi:10.1016/j.precamres.2020.105770

Nutman, A. P., Bennett, V. C., Friend, C. R. L., Hidaka, H., Yi, K., Lee, S. R., et al. (2013). The Itsaq gneiss complex of Greenland: episodic 3900 to $3660 \mathrm{Ma}$ juvenile crust formation and recycling in the 3660 to $3600 \mathrm{Ma}$ Isukasian orogeny. Am. J. Sci. 313, 877-911. doi:10.2475/09.2013.03

Nutman, A. P., Bennett, V. C., Friend, C. R. L., Jenner, F., Wan, Y., and Liu, D.-Y. (2009). "Episodic Eoarchaean crustal accretion (3.87 to $3.66 \mathrm{Ga}$ ) in West Greenland (Itsaq gneiss complex) and in northeastern China," in Earth Accretionary Systems in Space and Time. Editors P. A. Cawood and A. Kröner (London: Geological Society of London, Special Publications), 318, 127-154.

Nutman, A. P., Bennett, V. C., and Friend, C. R. L. (2015b). Proposal for a continent 'Itsaqia' amalgamated at $3.66 \mathrm{Ga}$ and rifted apart from $3.53 \mathrm{Ga}$ : initiation of a Wilson Cycle near the start of the rock record. Am. J. Sci. 315, 509-536. doi:10.2475/06.2015.01

Nutman, A. P., Bennett, V. C., Friend, C. R. L., and Rosing, M. T. (1997a). 3710 and $>3790 \mathrm{Ma}$ volcanic sequences in the Isua (Greenland) supracrustal belt; structural and Nd isotope implications. Chem. Geol. 141, 271-287. doi:10.1016/ s0009-2541(97)00084-3

Nutman, A. P., Bennett, V. C., and Friend, C. R. L. (2015a). The emergence of the Eoarchaean proto-arc: evolution of a c. $3700 \mathrm{Ma}$ convergent plate boundary at Isua, southern West Greenland, Geological Society, Lond., Special Publications, 389, 113-133. doi:10.1144/sp389.5

Nutman, A. P., Friend, C. R. L., Baadsgaard, H., and McGregor, V. R. (1989). Evolution and assembly of Archean gneiss terranes in the Godthåbsfjord region, southern west Greenland: structural, metamorphic, and isotopic evidence. Tectonics 8, 573-589. doi:10.1029/tc008i003p00573

Nutman, A. P., Friend, C. R. L., Barker, S. L. L., and McGregor, V. R. (2004). Inventory and assessment of Palaeoarchaean gneiss terrains and detrital zircons in southern West Greenland. Precambrian Res. 135, 281-314. doi:10.1016/j. precamres.2004.09.002

Nutman, A. P., Friend, C. R. L., and Hiess, J. (2010). Setting of the 2560 Ma Qorqut Granite Complex in the Archean crustal evolution of southern West Greenland. Am. J. Sci. 310, 1081-1114. doi:10.2475/09.2010.12

Nutman, A. P. and Friend, C. R. L. (2009). New 1:20,000 scale geological maps, synthesis and history of investigation of the Isua supracrustal belt and adjacent orthogneisses, southern West Greenland: a glimpse of Eoarchaean crust formation and orogeny. Precambrian Res. 172, 189-211. doi:10.1016/j. precamres.2009.03.017

Nutman, A. P. and Friend, C. R. L. (2006). Petrography and geochemistry of apatites in banded iron formation, Akilia, W. Greenland: consequences for oldest life evidence. Precambrian Res. 147, 100-106. doi:10.1016/j.precamres. 2006.02.005

Nutman, A. P. and Kalsbeek, F. (1994). A minimum age of $2944 \pm 7$ Ma for the Tartoq group, south-west Greenland. Rapp. Grønlands geol. Unders. 161, 35-38.

Nutman, A. P., McGregor, V. R., Friend, C. R. L., Bennett, V. C., and Kinny, P. D. (1996). The Itsaq Gneiss Complex of southern West Greenland; the world's most extensive record of early crustal evolution (3900-3600 Ma). Precambrian Res. 78, 1-39. doi:10.1016/0301-9268(95)00066-6

Nutman, A. P., McGregor, V. R., Shiraishi, K., Friend, C. R. L., Bennett, V. C., and Kinny, P. D. (2002). ₹3850 Ma BIF and mafic inclusions in the early Archaean Itsaq Gneiss Complex around Akilia, southern West Greenland? The difficulties of precise dating of zircon-free protoliths in migmatites. Precambrian Res. 117, 185-224. doi:10.1016/s0301-9268(02)00045-1

Nutman, A. P., Mojzsis, S. J., and Friend, C. R. L. (1997b). Recognition of $\geq 3850 \mathrm{Ma}$ water-lain sediments in West Greenland and their significance for the early Archaean Earth. Geochem. Cosmochim. Acta 61, 2475-2484. doi:10.1016/ s0016-7037(97)00097-5

Nutman, A. P. (1997). "The Greenland sector of the north atlantic craton," in Greenstone Belts. Editors M. J. de Wit and L. D. Ashwal (Oxford: Clarendon Press), 665-674.

Olsen, H. K. and Grahl-Madsen, L. (1994). Prospecting in the early Archean Isua supracrustals. Nunaoil A/S, 1994. Exploration license no. 01/93. Internal report 
$21 \mathrm{pp}$. (in archives of the Geological Survey of Denmark and Greenland, GEUS Report file 21329).

Ordóñez-Calderón, J. C., Polat, A., Fryer, B. J., Appel, P. W. U., van Gool, J. A. M., Dilek, Y., et al. (2009). Geochemistry and geodynamic origin of the Mesoarchean Ujarassuit and Ivisaartoq greenstone belts, SW Greenland. Lithos 113, 133-157. doi:10.1016/j.lithos.2008.11.005

O’Neill, C., Turner, C., and Rushmer, T. (2018). The inception of plate tectonics: a record of failure. Phil. Trans. Roy. Soc. Lond. A376, 20170414. doi:10.1098/rsta. 2017.0414

Pease, V., Percival, J., Smithies, H., Stevens, G., and Van Kranendonk, M. (2008). When did plate tectonics begin? Evidence from the orogenic record. Geol. Soc. Am., Special Paper, 440, 199-228. doi:10.1130/2008.2440(10)

Platt, J. P. (1986). Dynamics of orogenic wedges and the uplift of high-pressure metamorphic rocks. Geol. Soc. Am. Bull. 97, 1037-1053. doi:10.1130/00167606(1986)97<1037:doowat $>2.0 . c 0 ; 2$

Polat, A., Appel, P. W. U., Frei, R., Pan, Y., Dilek, Y., Ordóñez-Calderón, J. C., et al. (2007). Field and geochemical characteristics of the Mesoarchean ( 3075Ma) Ivisaartoq greenstone belt, southern West Greenland: evidence for seafloor hydrothermal alteration in supra-subduction oceanic crust. Gondwana Res. 11, 69-91. doi:10.1016/j.gr.2006.02.004

Polat, A., Appel, P. W. U., and Fryer, B. J. (2011). An overview of the geochemistry of Eoarchean to Mesoarchean ultramafic to mafic volcanic rocks, SW Greenland: implications for mantle depletion and petrogenetic processes at subduction zones in the early Earth. Gondwana Res. 20, 255-283. doi:10.1016/j. gr.2011.01.007

Polat, A., Frei, R., Scherstén, A., and Appel, P. W. U. (2010). New age (ca. 2970Ma), mantle source composition and geodynamic constraints on the Archean Fiskenæsset anorthosite complex, SW Greenland. Chem. Geol. 277, 1-20. doi:10.1016/j.chemgeo.2010.06.016

Polat, A. and Hofmann, A. W. (2003). Alteration and geochemical patterns in the 3.7-3.8 Ga Isua greenstone belt, West Greenland. Precambrian Res. 126, 197-218. doi:10.1016/s0301-9268(03)00095-0

Polat, A., Hofmann, A. W., and Rosing, M. T. (2002). Boninite-like volcanic rocks in the 3.7-3.8 Ga Isua greenstone belt, West Greenland: geochemical evidence for intra-oceanic subduction zone processes in the early Earth. Chem. Geol. 184, 231-254. doi:10.1016/s0009-2541(01)00363-1

Polat, A., Kerrich, R., and Windley, B. (2009). Archaean crustal growth processes in southern West Greenland and the southern Superior Province: geodynamic and magmatic constraints. Geol. Soc., Lond., Special Publications 318, 155-191. doi:10.1144/sp318.6

Polat, A., Kokfelt, T., Burke, K. C., Kusky, T. M., Bradley, D. C., Dziggel, A., et al. (2016). Lithological, structural, and geochemical characteristics of the Mesoarchean Târtoq greenstone belt, southern West Greenland, and the Chugach - prince William accretionary complex, southern Alaska: evidence for uniformitarian plate-tectonic processes. Can. J. Earth Sci. 53, 1336-1371. doi:10.1139/cjes-2016-0023

Polat, A., Wang, L., and Appel, P. W. U. (2015). A review of structural patterns and melting processes in the Archean craton of West Greenland: evidence for crustal growth at convergent plate margins as opposed to non-uniformitarian models. Tectonophysics 662, 67-94. doi:10.1016/j.tecto.2015.04.006

Rapp, R. P., Norman, M. D., Laporte, D., Yaxley, G. M., Martin, H., and Foley, S. F. (2010). Continent formation in the archean and chemical evolution of the cratonic lithosphere: melt-rock reaction experiments at 3-4 GPa and petrogenesis of Archean Mg-diorites (sanukitoids). J. Petrol. 51, 1237-1266. doi:10.1093/petrology/egq017

Rehnström, E. F. (2011). Geological Map of Greenland 1:100 000, Kapisillit 64 V.2 syd. Copenhagen: Geological Survey of Denmark and Greenland.

Rosing, M. T., Nutman, A. P., and Løfqvist, L. (2001). A new fragment of the early earth crust: the Aasivik terrane of West Greenland. Precambrian Res. 105, 115-128. doi:10.1016/s0301-9268(00)00107-8

Saintilan, N. J., Selby, D., Hughes, J. W., Schlatter, D. M., Kolb, J., and Boyce, A. (2020). Source of gold in Neoarchean orogenic-type deposits in the North Atlantic Craton, Greenland: insights for a proto-source of gold in sub-seafloor hydrothermal arsenopyrite in the Mesoarchean. Precambrian Res. 343, 105717. doi:10.1016/j.precamres.2020.105717

Scherstén, A. and Garde, A. A. (2013). Complete hydrothermal re-equilibration of zircon in the Maniitsoq structure, West Greenland: a 3001 Ma minimum age of impact? Meteoritics Planet Sci. 48, 1472-1498. doi:10.1111/maps.12169
Scherstén, A., Stendal, H., and Næraa, T. (2008). Geochemistry of greenstones in the Tasiusarsuaq terrane, southern West Greenland. Geol. Surv. Den. Greenl. Bull. 15, 69-72. doi:10.34194/geusb.v15.5047

Scherstén, A., Szilas, K., Creaser, R. A., Næraa, T., van Gool, J. A. M., and Østergaard, C. (2012). Re-Os and U-Pb constraints on gold mineralisation events in the Meso- to Neoarchaean Storø greenstone belt, Storø, southern West Greenland. Precambrian Res. 200-203, 149-162. doi:10.1016/j.precamres.2011. 12.014

Schiøtte, L., Compston, W., and Bridgwater, D. (1989). U-Pb single-zircon age for the Tinissaq gneiss of southern West Greenland: a controversy resolved. Chem. Geol. 79, 21-30. doi:10.1016/0168-9622(89)90004-3

Schlatter, D. M. and Christensen, R. (2010). Characterisation of host rocks and hydrothermal alteration of the Qussuk gold occurrence, southern West Greenland. Geol. Surv. Den. Greenl. Bull. 20, 63-66. doi:10.34194/geusb.v20.4963

Schlatter, D. M. and Stensgaard, B. M. (2014). Combining exploration and multivariate techniques to detect the Bjørnesund West gold occurrence, southern West Greenland. Geol. Surv. Den. Greenl. Bull. 31, 67-70.

Schumacher, J. C., van Hinsberg, V. J., and Keulen, N. (2011). Metamorphism in supracrustal and ultramafic rocks in southern West Greenland and South-West Greenland $64-61.5^{\circ}$ N. Geol. Surv. Den. Greenl. Rep. 6, 1-29.

Secher, K. (1983). Noritic rocks and associated nickel-copper-sulphide occurrences in Sukkertoppen district, central West Greenland. Rapp. Grønlands geol. Unders. 115, 30-34.

Shirey, S. B. and Richardson, S. H. (2011). Start of the Wilson Cycle at 3 Ga shown by diamonds from subcontinental mantle. Science 333, 434-436. doi:10.1126/ science. 1206275

Simmons, S. F., White, N. C., and John, D. A. (2005). "Geological characteristics of epithermal precious and base metal deposits," in Economic Geology 100th Anniversary (Littleton, CO: Society of Economic Geologists). 485-522. doi:10. 5382/av100.16

Sizova, E., Gerya, T., Stüwe, K., and Brown, M. (2015). Generation of felsic crust in the Archean: a geodynamic modeling perspective. Precambrian Res. 271, 198-224. doi:10.1016/j.precamres.2015.10.005

Smit, M. A., Scherstén, A., Næraa, T., Emo, R. B., Scherer, E. E., Sprung, P., et al. (2019). Formation of Archean continental crust constrained by boron isotopes. Geochem. Persp. Let. 12, 23-26. doi:10.7185/geochemlet.1930

Smith, C. P., Fagan, A. J., and Clark, B. (2016). Ruby and pink sapphire from Aappaluttoq, Greenland. J. Gemmol. 35, 294-306. doi:10.15506/jog.2016.35.4. 294

Souders, A. K., Sylvester, P. J., and Myers, J. S. (2013). Mantle and crustal sources of Archean anorthosite: a combined in situ isotopic study of $\mathrm{Pb}-\mathrm{Pb}$ in plagioclase and Lu-Hf in zircon. Contrib. Mineral. Petrol. 165, 1-24. doi:10.1007/s00410012-0789-6

Spencer, C. J., Kirkland, C. L., Roberts, N. M. W., Evans, N. J., and Liebmann, J. (2020). Strategies towards robust interpretations of in situ zircon Lu-Hf isotope analyses. Geosci. Front. 11, 843-853. doi:10.1016/j.gsf.2019.09.004

Steenfelt, A., Garde, A. A., and Moyen, J.-F. (2005). Mantle wedge involvement in the petrogenesis of Archaean grey gneisses in West Greenland. Lithos 79, 207-228. doi:10.1016/j.lithos.2004.04.054

Stendal, H. and Scherstén, A. (2007). A well-preserved bimodal Archaean volcanic succession in the Tasiusarsuaq terrane, South-West Greenland. Geol. Surv. Den. Greenl. Bull. 13, 53-56. doi:10.34194/geusb.v13.4975

Stern, R. J. (2008). "Modern-style plate tectonics began in Neoproterozoic times: an alternative interpretation of Earth's tectonic history," in When Did Plate Tectonics Begin on Planet Earth? Editors K. C. Condie and V. Pease (Boulder, CO: Geological Society of America, Special Paper), Vol. 440, 265-280.

Stern, R. J. (2010). The anatomy and ontogeny of modern intra-oceanic arc systems. Geol. Soc., Lond., Special Publications 338, 7-34. doi:10.1144/sp338.2

Stern, R. J. (2018). The evolution of plate tectonics. Phil. Trans. R. Soc. A. 376, 20170406. doi:10.1098/rsta.2017.0406

Szilas, K. (2018). A geochemical overview of mid-Archaean metavolcanic rocks from southwest Greenland. Geosciences 8 (0266), 20. doi:10.3390/ geosciences 8070266

Szilas, K., Elis Hoffmann, J., Scherstén, A., Rosing, M. T., Windley, B. F., Kokfelt, T. F., et al. (2012a). Complex calc-alkaline volcanism recorded in Mesoarchaean supracrustal belts north of Frederikshåb Isblink, southern West Greenland: implications for subduction zone processes in the early Earth. Precambrian Res. 208-211, 90-123. doi:10.1016/j.precamres.2012.03.013 
Szilas, K. and Garde, A. A. (2013). Mesoarchaean aluminous rocks at Storø, southern West Greenland: new age data and evidence of premetamorphic seafloor weathering of basalts. Chem. Geol. 354, 124-138. doi:10.1016/j. chemgeo.2013.07.001

Szilas, K., Hoffmann, J. E., Hansmeier, C., Hollis, J. A., Münker, C., Viehmann, S., et al. (2015). Sm-Nd and Lu-Hf isotope and trace-element systematics of Mesoarchaean amphibolites, inner Ameralik fjord, southern West Greenland. Mineral. Mag. 79, 857-876. doi:10.1180/minmag.2015.079.4.02

Szilas, K., Hoffmann, J. E., Scherstén, A., Kokfelt, T. F., and Münker, C. (2013a). Archaean andesite petrogenesis: insights from the Grædefjord supracrustal belt, southern west Greenland. Precambrian Res. 236, 1-15. doi:10.1016/j.precamres. 2013.07.013

Szilas, K., Hoffmann, J. E., Schulz, T., Hansmeier, C., Polat, A., Viehmann, S., et al. (2016a). Combined bulk-rock Hf- and Nd-isotope compositions of Mesoarchaean metavolcanic rocks from the Ivisaartoq Supracrustal Belt, SW Greenland: deviations from the mantle array caused by crustal recycling. Geochemistry 76, 543-554. doi:10.1016/j.chemer.2016.09.004

Szilas, K., Maher, K., and Bird, D. K. (2016b). Aluminous gneiss derived by weathering of basaltic source rocks in the Neoarchean Storø Supracrustal Belt, southern West Greenland. Chem. Geol. 441, 63-80. doi:10.1016/j.chemgeo. 2016.08.013

Szilas, K., Næraa, T., Scherstén, A., Stendal, H., Frei, R., van Hinsberg, V. J., et al. (2012b). Origin of Mesoarchaean arc-related rocks with boninite/komatiite affinities from southern West Greenland. Lithos 144-145, 24-39. doi:10.1016/j. lithos.2012.03.023

Szilas, K., Tusch, J., Hoffmann, J. E., Garde, A. A., and Münker, C. (2017). Hafnium isotope constraints on the origin of mesoarchaean andesites in southern West Greenland, North Atlantic craton. Geol. Soc., Lond., Special Public. 449, 19-38. doi: $10.1144 / \mathrm{sp} 449.2$

Szilas, K., van Gool, J. A. M., Scherstén, A., and Frei, R. (2014). The Neoarchaean Storø Supracrustal Belt, Nuuk region, southern West Greenland: an arc-related basin with continent-derived sedimentation. Precambrian Res. 247, 208-222. doi:10.1016/j.precamres.2014.04.010

Szilas, K., van Hinsberg, V. J., Kisters, A. F. M., Hoffmann, J. E., Windley, B. F., Kokfelt, T. F., et al. (2013b). Remnants of Arc-related mesoarchaean oceanic crust in the Tartoq group of SW Greenland. Gondwana Res. 23, 436-451. doi:10.1016/j.gr.2011.11.006

Szilas, K., van Hinsberg, V., McDonald, I., Næraa, T., Rollinson, H., Adetunji, J., et al. (2018). Highly refractory Archaean peridotite cumulates: petrology and geochemistry of the Seqi ultramafic complex, SW Greenland. Geosci. Front. 9, 689-714. doi:10.1016/j.gsf.2017.05.003

Tang, M., Chen, K., and Rudnick, R. L. (2016). Archean upper crust transition from mafic to felsic marks the onset of plate tectonics. Science 351, 372-375. doi:10. 1126/science.aad5513

Tappe, S., Smart, K. A., Pearson, D. G., Steenfelt, A., and Simonetti, A. (2011). Craton formation in Late Archean subduction zones revealed by first Greenland eclogites. Geology 39, 1103-1106. doi:10.1130/g32348.1

Thébaud, N. and Rey, P. F. (2013). Archean gravity-driven tectonics on hot and flooded continents: controls on long-lived mineralised hydrothermal systems away from continental margins. Precambrian Res. 229, 93-104. doi:10.1016/j. precamres.2012.03.001

Thøgersen, G. J.-P., Stendal, H., and Zimmermann, H. D. (2006). Hydrothermal alteration along the Ataneq fault in the Nuuk region, west Greenland. Bull. Geol. Soc. Finland Special Issue 1, 161

Trowbridge, A., Garde, A. A., Melosh, H. J., and Andronicos, C. (2017). "iSALE numerical modelling of the Maniitsoq structure, in West Greenland: a crustalscale column of mechanical mixing reaching the Moho." 48th Lunar and Planetary Science Conference, Houston, TX, March 20 -24, 2017 (Houston, TX: Lunar and Planetary Science Institute). Abstract \#2305. van de Löcht, J. S., Hoffmann, J. E., Rosing, M. T., Sprung, P., and Münker, C. (2020). Preservation of eoarchean mantle processes in $\sim 3.8$ Ga peridotite enclaves in the Itsaq gneiss complex, southern west Greenland. Geochem. Cosmochim. Acta 280, 25. doi:10.1016/j.gca.2020.03.043

van Hinsberg, V., Crotty, C., Roozen, S., Szilas, K., and Kisters, A. (2018). Pressuretemperature history of the $>3$ Ga Tartoq greenstone belt in southwest Greenland and its implications for Archaean tectonics. Geosciences 8, 367. doi:10.3390/geosciences8100367

Van Kranendonk, M. J. (2011). Onset of plate tectonics. Science 333, 413-414. doi:10.1126/science.1208766

Waterton, P., Hyde, W. R., Tusch, J., Hollis, J. A., Kirkland, C. L., Kinney, C., et al. (2020). Geodynamic implications of synchronous norite and TTG formation in the 3 Ga Maniitsoq norite belt, West Greenland. Front. Earth Sci. 8, 562062. doi:10.3389/feart.2020.562062

Webb, A. A. G., Müller, T., Zuo, J., Haproff, P. J., and Ramírez-Salazar, A. (2020). A non-plate tectonic model for the Eoarchean Isua supracrustal belt. Lithosphere 12, 166-179. doi:10.1130/11130.1

Wedepohl, K. H., Heinrichs, H., and Bridgwater, D. (1991). Chemical characteristics and genesis of the quartz-feldspathic rocks in the Archean crust of Greenland. Contrib. Mineral. Petrol. 107, 163-179. doi:10.1007/ bf00310705

Wells, P. R. A. (1979). Chemical and thermal evolution of Archaean sialic crust, southern West Greenland. J. Petrol. 20, 187-226. doi:10.1093/petrology/20.2.187

Whitehouse, M. J., Myers, J. S., and Fedo, C. M. (2009). The Akilia controversy: field, structural and geochronological evidence questions interpretations of $>3.8 \mathrm{Ga}$ life in SW Greenland, J. Geol. Soc. 166, 335-348. doi:10.1144/0016-76492008-070

Wilhem, C., Windley, B. F., and Stampfli, G. M. (2012). The Altaids of Central Asia: a tectonic and evolutionary innovative review. Earth Sci. Rev. 113, 303-341. doi:10.1016/j.earscirev.2012.04.001

Windley, B. F. and Bridgwater, D. (1971). The evolution of Archaean low- and high-grade terrains. Geol. Soc. Australia, Spec. Publication 3, 33-46.

Windley, B. F. and Garde, A. A. (2009). Arc-generated blocks with crustal sections in the North Atlantic Craton of West Greenland: crustal growth in the Archean with modern analogues. Earth Sci. Rev. 93, 1-30. doi:10.1016/j.earscirev.2008. 12.001

Windley, B. F. (1995). The Evolving Continents. 3rd edition. Chichester: Wiley, 526 pp.

Windley, B. F., Kusky, T., and Polat, A. (2020). Onset of plate tectonics by the Eoarchean. Precambrian Res. doi:10.1016/j.precamres.2020.105980

Winther, K. T. and Newton, R. C. (1991). Experimental melting of hydrous low-K tholeiite: evidence on the origin of Archaean cratons. Bull. Geol. Soc. Den. 39, 213-228.

Yakymchuk, C., Kirkland, C. L., Hollis, J. A., Kendrick, J., Gardiner, N. J., and Szilas, K. (2020). Mesoarchean partial melting of mafic crust and tonalite production during high-T-low-P stagnant tectonism, Akia Terrane, West Greenland. Precambrian Res. 339, 105615. doi:10.1016/j.precamres.2020. 105615

Conflict of Interest: The authors declare that the research was conducted in the absence of any commercial or financial relationships that could be constructed as a potential conflict of interest.

Copyright (c) 2020 Garde, Windley, Kokfelt and Keulen. This is an open-access article distributed under the terms of the Creative Commons Attribution License (CC BY). The use, distribution or reproduction in other forums is permitted, provided the original author(s) and the copyright owner(s) are credited and that the original publication in this journal is cited, in accordance with accepted academic practice. No use, distribution or reproduction is permitted which does not comply with these terms. 